\title{
Characterization, cytotoxicity, and genotoxicity properties of novel biomediated nanosized-silver by Egyptian Streptomyces roseolus for safe antimicrobial applications
}

\author{
Asmaa Elnady $^{1} \cdot$ Noha M. Sorour ${ }^{2}$ (D) $\cdot$ Rateb N. Abbas $^{1}$
}

Received: 10 September 2021 / Accepted: 7 January 2022 / Published online: 27 January 2022

(c) The Author(s) 2022

\begin{abstract}
Multi-drug resistant bacteria are not effectively managed with current treatments, making it a serious global problem. Therefore, there is an essential need for finding new antimicrobial agents. In this regard, silver nanoparticles (Ag-NPs) have been projected as a new generation of antimicrobial agents. Ag-NPs were biomediated by Egyptian Streptomyces roseolus for the first time, which was molecularly identified using 16S rRNA sequencing under accession no. MT071505. Biosynthesized Ag-NPs were characterized using UV-Vis spectroscopy, XRD, TEM, FTIR, and DLS. FTIR analysis confirmed the presence of different bioactive functional groups, such as $\mathrm{N}-\mathrm{H}, \mathrm{C}-\mathrm{H}, \mathrm{C}-\mathrm{O}-\mathrm{C}, \mathrm{C}-\mathrm{NH}_{2}$, and $\mathrm{C}=\mathrm{O}$ acting as bioreducing/ stabilizing agents for Ag-NPs. Ag-NPs exhibited antimicrobial activity against some multi-drug resistant Gram-positive and Gram-negative pathogens. MBC of Ag-NPs against Listeria monocytogenes and Klebsiella pneumonia were 0.195 and $0.048 \mathrm{mg} / \mathrm{mL}$, respectively, with a tolerance level of 2 confirming its biocidal effect. SEM imaging of Ag-NPs-treated L. monocytogenes and K. pneumonia showed shrunk destroyed cells after $6 \mathrm{~h}$ of treatment. Biosynthesized Ag-NPs exhibited $\mathrm{IC}_{50}$ of $<0.3$ and $8.21 \mathrm{mg} / \mathrm{mL}$, on normal Human Skin Fibroblast, and Blood Lymphocytes, respectively. IC $_{50}$ values were significantly higher than its MBC values, with no harmful cytotoxic effect, thus can be safely applied at its biocidal concentration. For biosafety purposes, the genotoxicity of biosynthesized Ag-NPs was assessed using Comet assay for the first time on Blood Lymphocytes, with zero-tail and 100\% head intensity indicating non-genotoxic effect. An ecofriendly biomediated synthesis of Ag-NPs was described with easy scale-up, non-toxic by-products, so, it can be recommended as a powerful-safe antimicrobial agent.
\end{abstract}

Noha M. Sorour

noha.sorour@mail.mcgill.ca

1 Department of Microbial Biotechnology, Genetic Engineering and Biotechnology Research Institute (GEBRI), University of Sadat City, Sadat City, 22857/79, Egypt

2 Department of Industrial Biotechnology, Genetic Engineering and Biotechnology Research Institute, University of Sadat City, Sadat City, 22857/79, Egypt 
Graphical abstract

\section{Isolation of new Streptomyces sp. and its molecular identification}
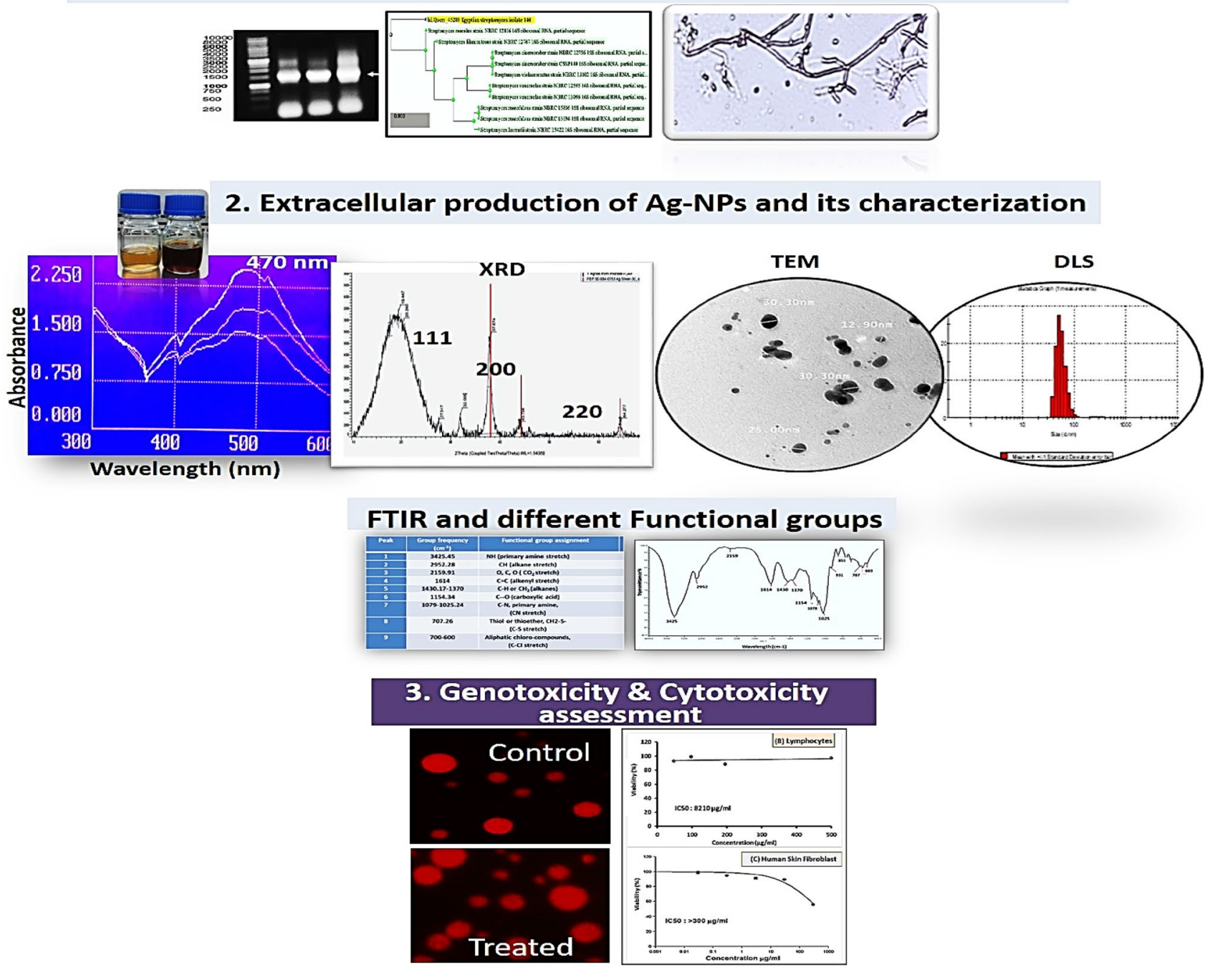

\section{Safe applications as bioagent}

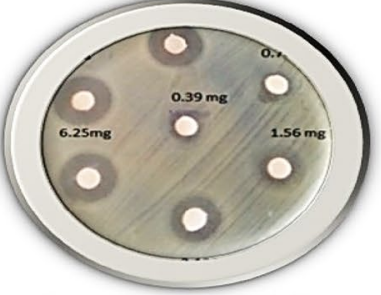

Antimicrobial activity against drug-resistant pathogens

Keywords Streptomyces · Antimicrobial · Cytotoxicity · Genotoxicity · NanoSilver 


\section{Introduction}

Multi-drug resistant bacteria are not effectively managed with current treatments, making it a serious global problem for public health. Accordingly, there is a strong need to develop new bactericides (Wypij et al. 2018). The increasing incidence of multidrug-resistant pathogens responsible for nosocomial infections has been detected in different health-care facilities in Egypt, where, Gram-negative bacteria were the most common pathogens (Saied et al. 2011; Fakhr and Fathy 2018; Hassan et al. 2021). The antibiotic resistance pattern among patients showed the prevalence of methicillin-resistant $S$. aureus (MRSA), extended-spectrum beta-lactamase bacteria, Cephalosporin resistant $K$. pneumoniae, Carbapenem resistant K. pneumonia, and the multidrug resistant- $P$. aeruginosa, E. coli, and Acinetobacter baumannii spp. (Fakhr and Fathy 2018; Hassan et al. 2021).

Recently, metallic nanoparticles (NPs) have gained great significance in the modern era of nanomaterials because of their unique intrinsic properties based on their morphology, size, and distribution (El-Baz et al. 2016; Mourdikoudis et al. 2018). These new properties are excellent physicochemical, electrical conductivity, catalytic, and mechanical stability (Srikar et al. 2016; Hassan et al. 2019; Crisan et al. 2021). Among metallic NPs, Ag-NPs have found tremendous applications in catalysis, biosensing, drug delivery, and medicine, etc. Currently, there has been an increasing interest in Ag-NPs because of their antimicrobial property, and even has been projected as a new generation of antimicrobial agents (Martínez et al. 2021). Therefore, Ag-NPs have been exploited for various applications, in household and healthcare-related products, wound dressings, medical device coatings, and cosmetics (Zhang et al. 2016; Wypij et al. 2018; Vanlalveni et al. 2021).

Although physicochemical synthesis generates stable monodispersed NPs with various shapes, these methods aren't recommended, because they involve the use of chemical reagents, require costly reaction setup, and generate toxic end-products causing environmental pollution (Srikar et al. 2016; Yaqoob et al. 2020). These drawbacks, make it very important to search for eco-friendly, and cost-effective approaches for the synthesis of NPs. Interestingly, microorganisms are considered nano-factories that play a vital role in the bioremediation of toxic metals through the reduction of metal ions (Anandaradje et al. 2020). In this respect, the actinomycetes members of the bacterial order Actinomycetales are found worldwide in soil, where Streptomyces, the largest genus of actinobacteria are considered efficient candidates for extracellular biosynthesis of metallic NPs with very good stability (Wypij et al. 2018). Furthermore, microorganisms or their secondary metabolites contain different biomolecules, which act as reducing and/or stabilizing agents for Ag-NPs and represent a safe approach than the physicochemical methods (Anandaradje et al. 2020). These natural reducing agents contain many functional groups which can increase the reduction capability and improve the stability of Ag-NPs (Zhang et al. 2016). Herein, the main objective of this study was to achieve a green approach for the biosynthesis of Ag-NPs using new Streptomyces strain isolated from the Egyptian soil. Characterization of the produced Ag-NPs was investigated, and its antimicrobial activity was tested against different pathogens. For biosafety applications, the cytotoxicity effect of biosynthesized AgNPs has been tested on different cell lines, and for the first time, its genotoxicity was assessed using Comet assay.

\section{Material and methods}

\section{Materials}

$\mathrm{AgNO}_{3}$ as a precursor for Ag-NPs synthesis was obtained from Sigma/Aldrich, USA. Peptone, Yeast extract, Malt extract, Glucose, Starch, and Dimethyl Sulphoxide (DMSO) were purchased from Lobal Chemie, India. All materials used for cell culture experiments were obtained from Cambrex BioScience (Copenhagen, Denmark). All other chemicals and reagents were bought locally and were analytically reagent grade from Algomhoryia Company for Chemicals, Cairo, Egypt.

\section{Culture media and microorganisms}

Glucose Yeast Malt medium was used for actinomycetes isolation having the following composition $(\mathrm{g} / \mathrm{L})$; malt extract 10 , yeast extract 3 , glucose 3 , agar 20 , and $\mathrm{pH} 7.3 \pm 0.1$. Starch nitrate medium was used as a synthetic medium for the biosynthesis of Ag-NPs (Abd-Elnaby et al. 2016) with the following composition (g/L); starch 20, $\mathrm{K}_{2} \mathrm{HPO}_{4} 0.5, \mathrm{KNO}_{3} 1$, $\mathrm{MgSO}_{4} .7 \mathrm{H}_{2} \mathrm{O} 0.5, \mathrm{FeSO}_{4} 0.01, \mathrm{KCl} 0.5$, and $\mathrm{pH} 7.2 \pm 0.2$. Nutrient agar medium was used for growth and maintenance of pathogens with the following composition $(\mathrm{g} / \mathrm{L})$; beef extract 3, peptone 5, $\mathrm{NaCl} 5$, agar 20, and $\mathrm{pH} 7$. Gram-positive bacteria (Bacillus cereus ATCC 14,579, Bacillus subtilis ATCC 6633, Listeria monocytogenes ATCC 19,116, Staphylococcus aureus ATCC 6538), Gram-negative strains (Escherichia coli O157:H7, Klebsiella pneumonia, Aeromonas hydrophilia), and Yeast (Candida albicans) were obtained from Dar Al-Fouad Hospital at 6th of October City, Cairo, and El-Mabarra Educational Hospital, Alexandria, Egypt.

\section{Isolation of actinomycetes}

Soil samples were collected in sterile plastic bags from Menuf, Minufyia governorate, Egypt. $10 \mathrm{~g}$ of collected 
sample was suspended in $90 \mathrm{~mL}$ of saline solution $(0.9 \%$ $\mathrm{NaCl}, \mathrm{w} / \mathrm{v}$ ), serially diluted, and $1 \mathrm{~mL}$ aliquot of each dilution was plated on sterile agar plates containing Glucose Yeast Malt Agar medium and was incubated for 5 days at $30{ }^{\circ} \mathrm{C}$. Colonies that were morphologically identified as actinomycetes were selected. Pure developed single colonies were obtained by conventional streak plate technique, kept at $4{ }^{\circ} \mathrm{C}$ on slants. All cultures were routinely stored in glycerol solution $(25 \% \mathrm{v} / \mathrm{v})$ at $-80{ }^{\circ} \mathrm{C}$.

\section{Biosynthesis of Ag-NPs}

Cell-free extract of the isolated actinomycete was grown in $250 \mathrm{~mL}$-Erlenmeyer flask containing starch nitrate broth medium, incubated in a rotary shaker (New Brunswick, CA) at $170 \mathrm{rpm}$ and $30^{\circ} \mathrm{C}$ for 3 days. After the incubation, culture was centrifuged at $6000 \mathrm{rpm}$ for $20 \mathrm{~min}$, and the collected supernatant was used for the biosynthesis of Ag-NPs. $50 \mathrm{~mL}$ of $\mathrm{AgNO}_{3}$ solution $(1 \mathrm{mM})$ was mixed with $50 \mathrm{~mL}$ of the actinomycete supernatant (Abd-Elnaby et al. 2016). The mixture was incubated at $30^{\circ} \mathrm{C}$ and $170 \mathrm{rpm}$ agitation at different temperature degrees $\left(30,45\right.$, and $\left.60^{\circ} \mathrm{C}\right)$ for $24 \mathrm{~h}$ at $150 \mathrm{rpm}$ in the rotatory shaker. Control experiments were carried out by mixing $\mathrm{AgNO}_{3}$ solution and un-inoculated media or adding the actinomycete supernatant without $\mathrm{AgNO}_{3}$. The reduction of $\mathrm{Ag}^{+}$ions was checked by the color change of the reaction mixture.

\section{Characterization of biosynthesized Ag-NPs}

\section{UV-Visible spectroscopy (UV-Vis) and X-ray diffraction (XRD)}

The formation of Ag-NPs during the biosynthesis was monitored using a UV-Vis spectrophotometer (Shimadzu T80 spectrophotometer, China). $1 \mathrm{~mL}$ aliquot of biosynthesized Ag-NPs colloidal solution was scanned at a wavelength ranging from 300 to $700 \mathrm{~nm}$. The crystalline natures of the biosynthesized Ag-NPs powder were investigated by X-ray diffraction (Bruker D2 Phaser diffractometer 2nd Gen.), operating at (50 kV and $0.5 \mathrm{~mA})$, with a $\mathrm{Cu}$ anode radiation $(1.54060 \AA)$ in the angular range of $10^{\circ}-70^{\circ}$ using continuous scanning $2 \theta$ mode. The size of the Ag-NPs formed in the bio-reduction process was determined using Scherrer's formula (Sumadevi et al. 2021).

$\mathrm{D}=\mathrm{K} \lambda / \beta \cos \theta$

$\mathrm{K}$ is the Scherrer constant (shape factor), $\lambda$ is the X-ray wavelength $(1.5418 \AA), \beta$ is the width of the XRD peak at half-height, $\theta$ is the Bragg angle, and $D$ is the grain size.

\section{Transmission electron microscope (TEM), dynamic light scattering (DLS), and fourier transform infrared (FTIR)}

The size and morphology of the biosynthesized Ag-NPs were studied by TEM (FETEM, JSM-2100F, JEOL Inc.) at Petroleum Research Institute, Cairo, Egypt. An aliquot of Ag-NPs suspension was transferred onto carbon-coated copper grid, and allowed to dry. The grid was then scanned using TEM (Phillips EM 208S) operated at $100 \mathrm{kV}$ voltage. Ag-NPs were analyzed using Nano-Zeta Sizer (Nano ZS, ZEN 3600, Malvern Nano, UK) to determine the distribution of particles size. DLS measures the light scattered from a laser when passes through the sample and the fluctuations of the scattered light are detected at a known scattering angle $\theta$ by a fast photon detector (Fissan et al. 2014). The FTIR spectrum of the dried biosynthesized Ag-NPs sample was recorded on an FTIR spectrometer 8000 series, with $\mathrm{KBr}$ in the wavenumber region of $4000-400 \mathrm{~cm}^{-1}$ at a resolution of $4 \mathrm{~cm}^{-1}$. To identify the functional groups found in the tested sample, the spectral data recorded were compared with the reference database.

\section{Molecular identification and phylogenetic analysis}

The selected actinomycetes isolate was identified using $16 \mathrm{~S}$ rRNA gene partial sequencing method (Kim et al. 2011). Genomic DNA of the selected actinomycetes isolate was extracted using genomic DNA Extraction Kit (Intron, Biotechnology, Korea). PCR amplification of 16S ribosomal DNA (16S rDNA) was performed with a set of universal primers; 27F-Forward primer 5'AGA GTT TGA TCC TGG CTC AG 3' (20 mer) and 1492R-Reverse primer 5'CTA CGG CTA CCT TGT TAC GA 3' (20 mer). The PCR amplification was performed using a programmed thermal cycler (Thermo Fisher Scientific, USA). The produced amplicons of the selected isolate (PCR product) were tested for their quality by electrophoresis in Bio-Rad submarine $(8 \times 12 \mathrm{~cm})$ using agarose gel (1\%) and compared with $1 \mathrm{~kb}$ DNA ladder (Intron Biotechnology, Korea). DNA banding patterns of 16S gene amplicons were visualized using a UV-transilluminator (Thermo Fisher Scientific, USA) under UV light. PCR products were purified using gene JET ${ }^{\mathrm{TM}}$ genomic DNA purification kit (Intron Biotechnology, Korea) according to the manufacturer's instructions. Then sequenced using forward and reverse primers with ABI 3730xl DNA sequencer. Nucleotide bases obtained after sequencing were identified and compared with similar sequences retrieved from the GenBank database within the National Center for Biotechnology Information (NCBI) (http://www.ncbi.nlm.nih.gov/ GenBank/index.html) using nucleotide Basic Local Alignment Search Tool (BLAST) Gene Sequences in the database website (http://www.ncbi.nlm.gov/BLAST/L. The nucleotide 
sequences of the 16S rRNA genes was deposited under accession number MT071505. The phylogenetic analysis of sequences was created using MEGA integrated software for Molecular Evolutionary Genetics Analysis and sequence alignment (http://www.megasoftware.net/L. The statistical method is maximum likelihood, and the test of phylogeny is Bootstrap method with no. of bootstrap replication equal to 500 based on Tamura-Nei model (Tamura and Nei 1993; Stecher et al. 2020).

\section{Qualitative and quantitative assessment of antimicrobial activity}

\section{Bacterial strains and growth conditions}

The antimicrobial activity of the biosynthesized Ag-NPs was tested against different Gram-positive bacteria (L. monocytogenes, S. aureus, B. subtilis, B. cereus), Gram-negative bacteria (E. coli $\mathrm{O} 157: \mathrm{H} 7$, K. pneumonia, A. hydrophilia), and yeast (C. albicans). All bacterial strains were grown on nutrient broth, except $L$. monocytogenes was grown on brain heart infusion (Oxoid, ltd, England), and the yeast was grown on Wickerham medium. Stock inoculum suspensions of the pathogenic strains were freshly prepared by picking colonies from $24 \mathrm{~h}$ cultures grown on at $37^{\circ} \mathrm{C}$ and suspended in sterile saline solution $(0.9 \% \mathrm{NaCl}, \mathrm{w} / \mathrm{v})$. The optical density of pathogens was adjusted to achieve turbidity equivalent to $0.5 \mathrm{McF}$ arland standard, approximately $\left(1 \times 10^{8} \mathrm{CFU} / \mathrm{mL}\right)$ for bacteria, and $\left(1 \times 10^{6} \mathrm{CFU} / \mathrm{mL}\right)$ for $C$. albicans (Andrews 2001).

\section{Disc diffusion method}

Disc diffusion method is commonly used as a preliminary screening test prior to quantitative minimal inhibitory concentration (MIC) determination. Microbial inocula were spread on plates containing appropriate medium using sterile cotton swab, and plates were allowed to dry for $15 \mathrm{~min}$ at room temperature. Sterile filter paper discs (Hi media) were saturated by $40 \mu \mathrm{L}$ of two-fold serially diluted concentrations of biosynthesized Ag-NPs in the range $(0.39-25 \mathrm{mg} / \mathrm{mL})$. Discs saturated with the actinomycete supernatant and $\mathrm{AgNO}_{3}$ were used as a negative and positive control, respectively. The plates were incubated at $4{ }^{\circ} \mathrm{C}$ for $1 \mathrm{~h}$ to allow the diffusion of Ag-NPs into the medium and were incubated at $37{ }^{\circ} \mathrm{C}$ for $24 \mathrm{~h}$ (Wikler 2006). After incubation, inhibition zones diameters were measured in mm, and MIC was determined as the lowest concentration of Ag-NPs that produced an inhibition zone after $24 \mathrm{~h}$ of incubation.

\section{Agar dilution method}

Brain Heart Infusion (BHI) and nutrient agar (NA) media were used for the growth of L. monocytogenes and K. pneumonia, respectively. Two-fold serial dilutions of biosynthesized Ag-NPs were prepared in molten BHI agar and NA medium with desired final concentrations. Using the pourplate method (Klančnik et al. 2010), $100 \mu \mathrm{L}$ of L. monocytogenes or $K$. pneumonia bacterial suspensions (0.5 Mcfarland $\sim 1: 2 \times 10^{8} \mathrm{CFU} / \mathrm{mL}$ ) were inoculated into appropriate agar medium and incubated at $37{ }^{\circ} \mathrm{C}$ for $24 \mathrm{~h}$. An inoculated agar plate without Ag-NPs was served as a positive control and another one without inoculum as a negative control.

\section{Broth macro-dilution method, MIC, and MBC determination}

Broth macro-dilution was done according to Andrews (2001) method. The biosynthesized Ag-NPs were added to $10 \mathrm{~mL}$ of BHI broth medium and nutrient broth to give final concentrations, with respect to the results obtained by the agar dilution method. $100 \mu \mathrm{L}$ from the diluted culture of $L$. monocytogenes or K. pneumonia $\left(0.5 \sim\right.$ Mcfarland $1: 2 \times 10^{8} \mathrm{CFU} /$ $\mathrm{mL}$ ) were inoculated in growth media containing the desired concentration of Ag-NPs, well shaken, and incubated at 37 ${ }^{\circ} \mathrm{C}$ for $24 \mathrm{~h}$. Bacterial growth was followed by plating $1 \mathrm{~mL}$ from the incubated culture tubes and control on suitable media. After $24 \mathrm{~h}$ of incubation, plates were compared with the positive control, and the bacterial colony number was calculated as $(\mathrm{CFU} / \mathrm{mL})$. The MIC is the lowest concentration of biosynthesized Ag-NPs resulting in a significant reduction (99\%) of pathogen viability after $24 \mathrm{~h}$ of incubation. The concentration where $100 \%$ of microbial growth was inhibited as compared to the negative control (media only) was designed as MBC value. The tolerance level of pathogen towards the biosynthesized Ag-NPs was calculated using the following formula (May et al. 1998):

Level of Tolerance $=\mathrm{MBC} / \mathrm{MIC}$

\section{Scanning electron microscope (SEM) imaging}

The effect of biosynthesized Ag-NPs on pathogens was studied using SEM, micrographs were captured using Jeol JSM- 5300 SEM operated between 15 and $20 \mathrm{keV}$ at Faculty of Science, Alexandria University, Egypt. Samples were prepared according to Tamboli and Lee (2013) method with some modifications as follows; $10 \mathrm{~mL}$ of fresh bacterial culture of L. monocytogenes and K. pneumonia grown in Luria-Bertani medium for $18 \mathrm{~h}$ were treated with biosynthesized Ag-NPs at their MIC, then incubated for 3 and $6 \mathrm{~h}$. Treated bacterial cells were collected by centrifuging at 
$6000 \mathrm{rpm}$ for $10 \mathrm{~min}$. Culture supernatants were discarded and the treated cells were washed by phosphate saline buffer (pH 7.4) to remove excess of Ag-NPs, then centrifuged to collect washed cells. Samples were fixed by immersing immediately in an equal volume of a fixative solution (1\% glutaraldehyde, $4 \%$ paraformaldehyde in $0.1 \mathrm{M}$ sodiumcacodylate) at $4{ }^{\circ} \mathrm{C}$ for $24 \mathrm{~h}$. Samples were then post-fixed in $2 \% \mathrm{OsO}_{4}$ in the phosphate saline buffer $\left(\mathrm{pH} \mathrm{7.4)}\right.$ at $4{ }^{\circ} \mathrm{C}$ for $2 \mathrm{~h}$. Samples were washed in the buffer and dehydrated at $4{ }^{\circ} \mathrm{C}$ through graded series of ethanol then dried by $\mathrm{N}_{2}$ gas. Finally, the samples were mounted using carbon paste on AL-stub using double-sided conductive tapes and coated with gold up to a thickness of $400 \mathrm{~A}$ in a sputter-coating unit (JFC-1100 E).

\section{Cytotoxic assessment of biosynthesized Ag-NPs}

Cell viability and cytotoxicity of biosynthesized Ag-NPs were tested on normal Human Skin Fibroblast (HSF) cell lines using sulforhodamine B protein (SRB) assay and on Peripheral Blood Lymphocytes normal cells, as well as Human Hepatocellular Carcinoma (HepG-2) cell lines using MTT assay. Normal HSF cell lines were obtained from Nawah Scientific Inc., (Mokatam, Cairo, Egypt). Cells were maintained in Dulbecco's Minimum Essential Medium (DMEM) supplemented with $100 \mathrm{mg} / \mathrm{mL}$ of streptomycin, $100 \mathrm{U} / \mathrm{mL}$ of penicillin, and $10 \%$ of heat-inactivated fetal bovine serum in humidified $\mathrm{CO}_{2}(5 \% \mathrm{v} / \mathrm{v})$ at $37^{\circ} \mathrm{C}$. Aliquots of $100 \mu \mathrm{L}$ cell suspension $\left(5 \times 10^{3}\right.$ cells $)$ were distributed in 96-well plates and incubated for $24 \mathrm{~h}$. Cells were treated with an aliquot of $100 \mu \mathrm{L}$ media containing Ag-NPs $(0-300 \mu \mathrm{g} / \mathrm{mL})$ concentrations. After $72 \mathrm{~h}$ of exposure, cells were fixed using $150 \mu \mathrm{L}$ of TCA (10\%) and incubated for $1 \mathrm{~h}$ at $4{ }^{\circ} \mathrm{C}$. The TCA solution was removed, and cells were washed five times using double distilled water. Aliquots of $70 \mu \mathrm{L} \mathrm{SRB}$ solution $(0.4 \% \mathrm{w} / \mathrm{v})$ were added and incubated at $25^{\circ} \mathrm{C}$ in darkness for $10 \mathrm{~min}$. Plates were washed three times with acetic acid ( $1 \% \mathrm{v} / \mathrm{v})$ and allowed to air-dry. To dissolve the protein-bound SRB stain, $150 \mu \mathrm{L}$ of TRIS $(10 \mathrm{mM})$ was added, and the absorbance was measured at $540 \mathrm{~nm}$ using a BMGLABTECH®-FLUO star Omega microplate reader, Ortenberg, Germany (Skehan et al. 1990).

Hep-G2 cell lines (ATCC, USA) were used to evaluate the cytotoxic effect of the biosynthesized Ag-NPs using 3-[4,5-dimethylthiazole-2-yl]-2,5-diphenyltetrazolium bromide (MTT) assay. Cells were routinely cultured in DMEM, supplemented with $10 \%$ FBS, 2 mM L-glutamine, $100 \mathrm{U} /$ $\mathrm{mL}$ streptomycin-sulfate, $250 \mathrm{ng} / \mathrm{mL}$ amphotericin $\mathrm{B}$, and $100 \mathrm{U} / \mathrm{mL}$ sodium penicillin-G. Cells were maintained in humidified air containing $5 \% \mathrm{CO}_{2}$ at $37^{\circ} \mathrm{C}$. For sub-culturing, the monolayer cells were harvested after trypsin/EDTA treatment at $37{ }^{\circ} \mathrm{C}$. Peripheral Blood Lymphocytes were isolated from fresh blood samples according to Kizhakeyil et al. (2019). Lymphocyte cell suspension was centrifuged at $2000 \mathrm{rpm}$ for $10 \mathrm{~min}$, washed twice, then suspended in incomplete RPMI-1640. Lymphocyte cell viability was checked using Trypan blue stain (Sigma). The cells $(2.5 \times$ $10^{5}$ cells $/ \mathrm{mL}$ ) were cultured in RPMI-1640 supplemented with $10 \% \mathrm{FBS}$ as triplicates of $200 \mu \mathrm{L} /$ well into flat-bottom 96-well tissue culture plates (Griener) and incubated with biosynthesized Ag-NPs $(48-500 \mu \mathrm{g} / \mathrm{mL})$ for $48 \mathrm{~h}$ in a humidified $5 \% \mathrm{CO}_{2}$ atmosphere. HepG- 2 cells $\left(0.5 \times 10^{5}\right.$ cells/well), in serum-free medium, were plated in a flat-bottom 96-well microplate, and treated with $20 \mu \mathrm{L}$ of different Ag-NPs concentrations in the range $(62.5-500 \mu \mathrm{g} / \mathrm{mL})$ for $24 \mathrm{~h}$ at $37{ }^{\circ} \mathrm{C}$, in a humidified $5 \% \mathrm{CO}_{2}$. After incubation, $40 \mu \mathrm{L}$ of MTT solution/well were added after the removal of media and incubated for an additional $4 \mathrm{~h}$. MTT crystals were solubilized by the addition of $180 \mu \mathrm{L}$ of DMSO/ well, and plates were shacked at room temperature, followed by photometric determination of the absorbance at $570 \mathrm{~nm}$ using microplate ELISA reader (SunriseTM, Tecan Group Ltd. Männedorf/Switzerland). Each concentration was carried out in triplicate, the average and standard deviation were calculated. Data were expressed as the percentage $(\%)$ of relative viability as compared with untreated cells, with cytotoxicity indicated by $<100 \%$ relative viability. The extent of MTT reduction was quantified, where the number of viable cells was directly proportional to the intensity of formazan dark-blue color (Hansen et al. 1989). IC $_{50}$ was calculated from the dose-response curve and the percentage (\%) of relative viability was calculated using the following equation (Hansen et al. 1989):

[Absorbance of treated cells/Absorbance of control cells)] $\times 100$

\section{In vitro genotoxicity alkaline Comet assay}

The Comet assay was assessed according to Singh et al. (1988) with some modifications. Treated cells were incubated with different concentrations of biosynthesized AgNPs $(48-500 \mu \mathrm{g} / \mathrm{mL})$ for $12 \mathrm{~h}$, under proper sterilized anaerobic conditions. Cells were washed by phosphate saline buffer ( $\mathrm{pH}$ 7.4), resuspended in $0.75-1 \%$ low dissolving agarose (Bio-Rad), and were spread onto slides covered by $1 \%$ typical agarose. Slides were left to solidify at $40{ }^{\circ} \mathrm{C}$ for $5 \mathrm{~min}$, then were placed in lysis buffer $(2.5 \mathrm{M} \mathrm{NaCl}$, $10 \mathrm{mM}$ Tris, $100 \mathrm{mM}$ EDTA, $1 \%$ TritonX100, 10\% DMSO, $\mathrm{pH} 10$ ) overnight at $40{ }^{\circ} \mathrm{C}$. Slides were placed in unwinding buffer (300 mM NaOH, 1 mM EDTA, $\left.\mathrm{pH}^{>} 13\right)$ for $40 \mathrm{~min}$ at $40{ }^{\circ} \mathrm{C}$. Electrophoresis was carried out for $20 \mathrm{~min}$ at $25 \mathrm{~V}$ $(1.0 \mathrm{~V} / \mathrm{cm})$, and $300 \mathrm{~mA}$. Finally, the slides were neutralized using $0.4 \mathrm{M}$ Tris buffer ( $\mathrm{pH} 7.5$ ) and were stained with ethidium bromide $(20 \mu \mathrm{g} / \mathrm{mL})$, then examined using a fluorescence light microscope (Leica DMi8 S-platform, 
Germany), $100 \times$ objective lens. The tail intensity $\%$, head intensity, and tail moment were assessed using Comet examine IV software.

\section{Statistical analysis}

All experiments were conducted in triplicates, the mean and all standard deviations were calculated using Excel software (Microsoft office, 2010). Data were expressed in their mean values $\pm \mathrm{SD}$ (standard deviation).

\section{Results}

\section{Biosynthesis of Ag-NPs}

In this study, Ag-NPs were successfully synthesized extracellularly using the culture supernatant of new Streptomyces strain isolated from the Egyptian soil (Fig. 1). Interestingly, the culture supernatant incubated with $1 \mathrm{mM} \mathrm{AgNO}_{3}$ mediated the biosynthesis of Ag-NPs within $6 \mathrm{~h}$ of incubation. The color of the reaction mixture was changed from yellow to dark reddish-brown, which indicates the formation of Ag-NPs (Fig. 2), whereas, no color change was observed in either the culture supernatant without $\mathrm{AgNO}_{3}$ or un-inoculated media with $\mathrm{AgNO}_{3}$ as control. After $24 \mathrm{~h}$, the color was stable indicating that $\mathrm{AgNO}_{3}$ was completely reduced, and the reaction has come to an end.

\section{Molecular identification and the phylogenic tree of selected isolate}

PCR amplification of the DNA samples from the selected Streptomyces isolate \#140 generated a PCR product (Fig. 1) of expected size $(1500 \mathrm{bp})$. The analysis of $16 \mathrm{~S}$ rRNA gene of the Streptomyces isolate \#140 was sequenced with $27 \mathrm{~F}$ and 1492R primers at the forward and reverse directions. The NCBI database showed $98.74 \%$ of similarity with Streptomyces roseolus, under accession no. MT071505. Gene bank nucleotide database using the blast-n algorithm revealed significant matches with hi max score of 1818 , zero e value, and $98.74 \%$ nucleotide identity for forward 16 s rRNA gene sequence of Streptomyces isolate \#140 and that of Streptomyces roseolus strain (NBRC 12,816). Also, the reverse sequence shows hi max score of 1984 and zero e value with $98.01 \%$ identity with $S$. roseolus strain (NBRC 12,816). The phylogenetic tree (Fig. 1) shows high genetic relationship between the Egyptian Streptomyces isolate \#140 and $S$. roseolus strain (NBRC 12,816). The phylogenic tree shows a set of possible nucleotides at each ancestral node based on their incidental likelihood at site 1. Initial heuristic tree(s) were obtained using BioNJ algorithms and NeighborJoin to a matrix of pairwise-distances using Tamura-Nei

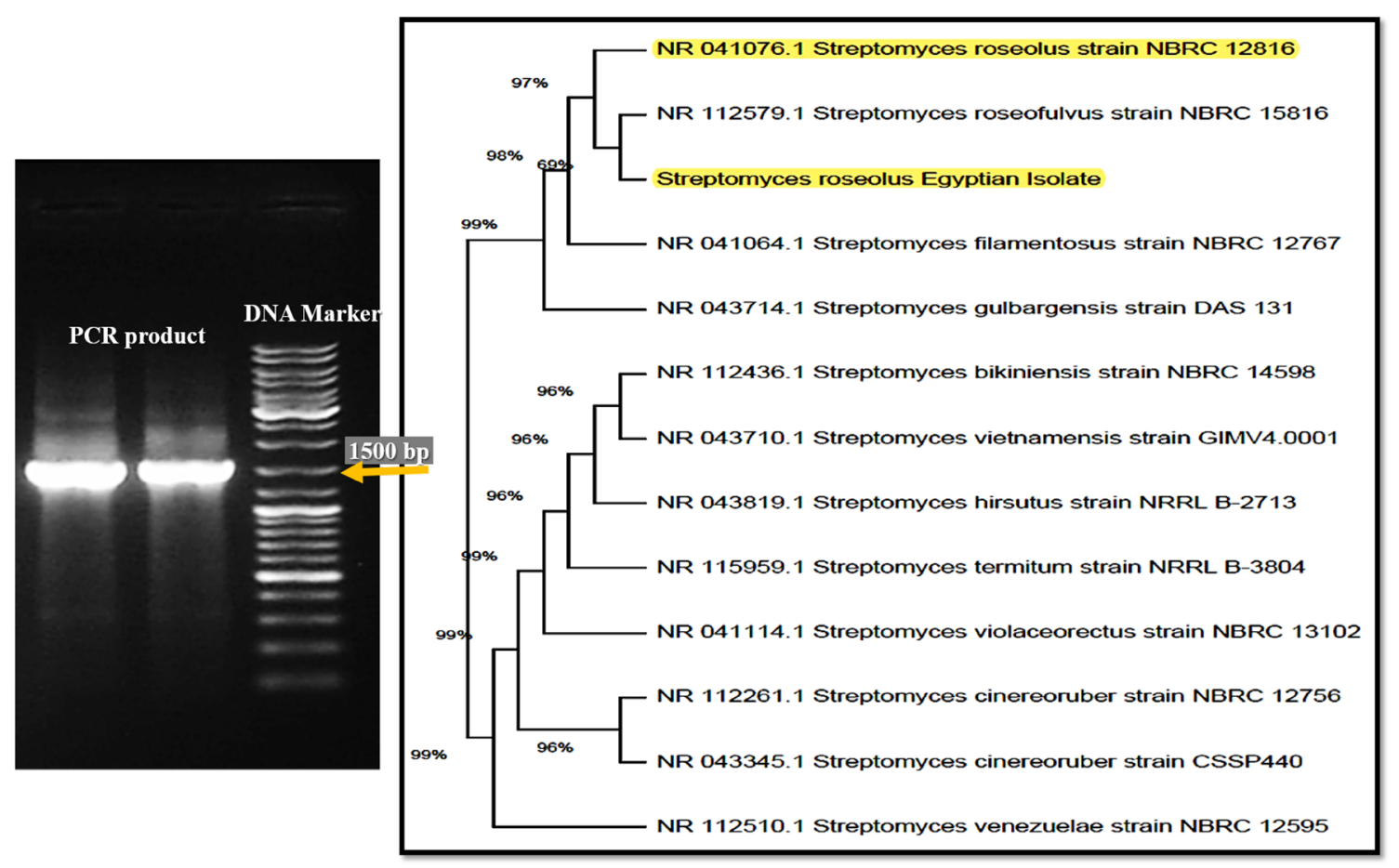

Fig. 1 Phylogenetic tree of 16S sequences of the Streptomyces isolate \#140 aligned with closely related sequences accessed from the GenBank under accession no. MT071505 

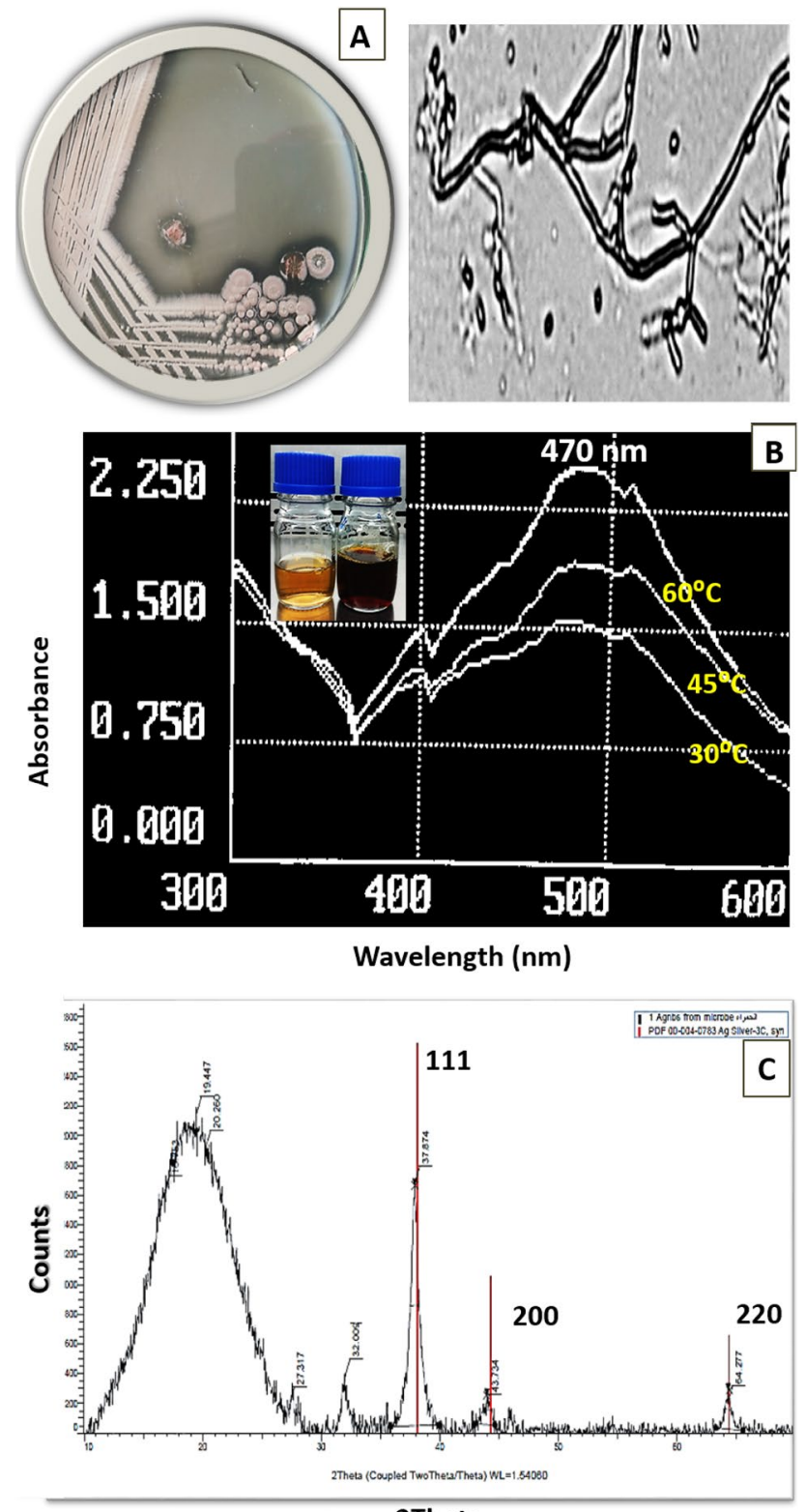

2Theta

Fig. 2 Streptomyces roseolus grown on starch nitrate agar medium and under light microscope *100 (A), UV-Vis Scanning of biosynthesized Ag-NPs by $S$. roseolus culture supernatant at different temperature (B), and XRD analysis of biosynthesized Ag-NPs (C)

model. Topology was selected with superior log likelihood value and the analysis involved 13 nucleotide sequences (Fig. 1).

\section{Characterization of biosynthesized Ag-NPs}

A strong and broad surface-plasmon-resonance (SPR) band maximum was observed at $470 \mathrm{~nm}$, characteristic for Ag-NPs (Fig. 2). The color intensity was increased with increasing the temperature, and consequently, the intensity of SPR peaks was increased (Fig. 2). The XRD pattern of the biosynthesized Ag-NPs by S. roseolus (Fig. 2) showed characteristic XRD diffraction peaks centered at 37.874, $43.734,64.277$ induced by the crystalline planes of $\mathrm{Ag}$ as, 111,200 , and 220, respectively, as indexed planes of cubic face-centered silver. Peaks intensity reflects the high degree of Ag-NPs crystallinity. According to Scherrer's equation, the average size of Ag-NPs was found to be $10.8 \mathrm{~nm}$. TEM micrograph showed the formation of well-dispersed spherical Ag-NPs biosynthesized by S. roseolus (Fig. 3). The size of Ag-NPs determined by TEM was 5-22 $\mathrm{nm}$. The DLS pattern demonstrated that Ag-NPs biosynthesized by $S$. roseolus had a $\mathrm{Z}$ average diameter of $56.33 \mathrm{~nm}$, and its polydispersity index (PDI) was 0.398. Results (Fig. 3) showed a bimodal scattered intensity distribution with a major maximum at about $56 \mathrm{~nm}$. The FTIR analysis (Fig. 4) verified the presence of different functional groups on the surface of biosynthesized Ag-NPs. Results showed specific strong absorption bands at 3420, 2952, 1614, and $1430 \mathrm{~cm}^{-1}$. Different absorbance peaks like 1370, 1154, and $1062 \mathrm{~cm}^{-1}$ were also detected.

\section{Antimicrobial activity of Ag-NPs}

The biosynthesized Ag-NPs exhibited an excellent dosedependent antimicrobial activity against different Gramnegative, Gram-positive bacteria, and yeast (Fig. 5 and Table 1). The highest antimicrobial activity was against Gram-negative bacteria. Among all pathogenic strains, the biosynthesized Ag-NPs exhibited higher antibacterial activity against $E$. coli $\mathrm{O} 157: \mathrm{H} 7$ with inhibition zone diameter of $23.66 \pm 0 \mathrm{~mm}$ (Table 1). The lowest activity was against $C$. albicans and $B$. subtilis with an inhibition zone of $18.66 \pm 0.3$ and $19.66 \pm 0.3 \mathrm{~mm}$, respectively.

\section{Quantitative determination of MIC, MBC, and tolerance level}

The MIC and MBC of biosynthesized Ag-NPs were determined as an estimation of their antimicrobial activity against the Gram-positive L. monocytogenes and Gram-negative $K$. pneumonia as multidrug-resistant pathogens. Table 2 shows that the MIC values for L. monocytogenes were 195 and $97 \mu \mathrm{g} / \mathrm{mL}$ using agar dilution and broth macro-dilution methods, respectively. The MBC values obtained by these two methods were very applicable at a concentration of $195 \mu \mathrm{g} /$ $\mathrm{mL}$ for the same strain. However, lower MIC values of $\mathrm{Ag}$ NPs were detected for the inhibition of the Gram-negative K. pneumonia at 48 and $24 \mu \mathrm{g} / \mathrm{mL}$, using agar dilution and broth macro-dilution, respectively. Results also indicated that the Gram-negative K. pneumonia was more sensitive to 


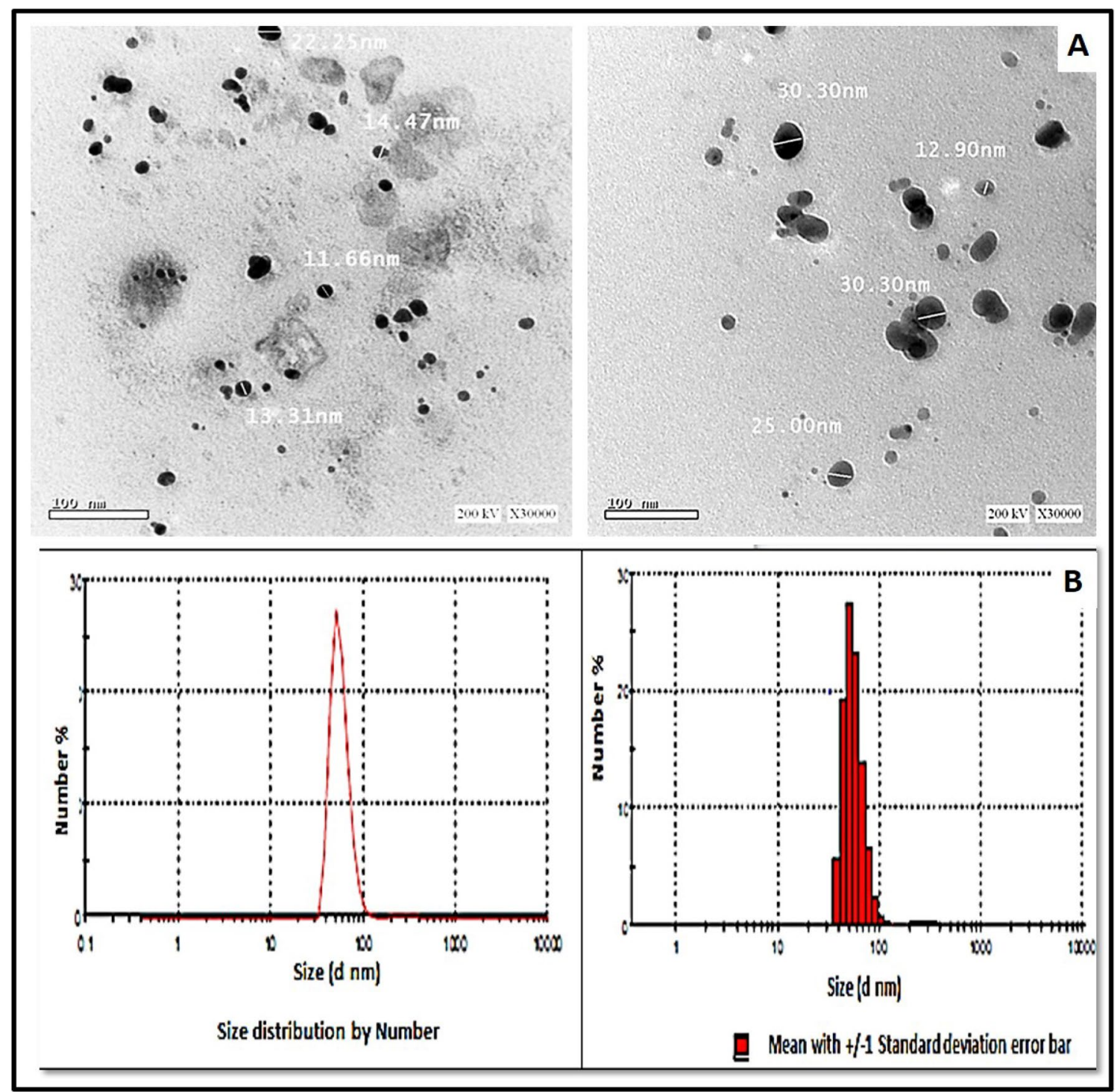

Fig. 3 TEM analysis of Ag-NPs biosynthesized by S. roseolus culture supernatant, and hydro-dynamic size determination of biosynthesized AgNPs by $S$. roseolus using DLS

Ag-NPs than the Gram-positive L. monocytogenes. Results in Table 2 show that the broth macro-dilution method is more sensitive than other screening agar methods, thus it is more suitable for rapid quantitative determination of the antimicrobial activity of Ag-NPs. The tolerance level of pathogens towards Ag-NPs was calculated from their respective MIC and MBC values (Table 2). The tolerance level was 2 using broth macro-dilution method, for L. monocytogenes, and $K$. pneumonia. In the current study, both $\mathrm{MIC}$ and MBC determined using the two dilution methods did not observe any visible growth when plated on solid media after $24 \mathrm{~h}$ of incubation, and the MBC was equal to or within 1 or 2 double its MIC.

\section{SEM imaging}

Cells treated with their MIC of biosynthesized Ag-NPs after 3 and $6 \mathrm{~h}$ of incubation showed notable morphological alterations as compared to the control with no treatment (Fig. 6). After $3 \mathrm{~h}$ of exposure to MIC concentrations, the treated L. monocytogenes and $K$. pneumonia cells were tiny, shrunk, diminutive, and dehydrated, with many pits in their surface. Some cells showed large leakage, others appeared misshapen and fragmented. After $6 \mathrm{~h}$ of exposure to AgNPs, the microbial cells were fully lysed, and the interior dehydrated cellular components and debris were the only observable matrix. 
Fig. 4 FTIR analysis of Ag-NPs biosynthesized by Streptomyces roseolus, showing different functional groups, such as, $\mathrm{N}-\mathrm{H}, \mathrm{C}-\mathrm{H}, \mathrm{C}-\mathrm{O}-\mathrm{C}, \mathrm{C}-\mathrm{S}$, $\mathrm{C}-\mathrm{NH}_{2}$, and $\mathrm{C}=\mathrm{O}$ acting as bioreducing/stabilizing agents for the biosynthesized Ag-NPs

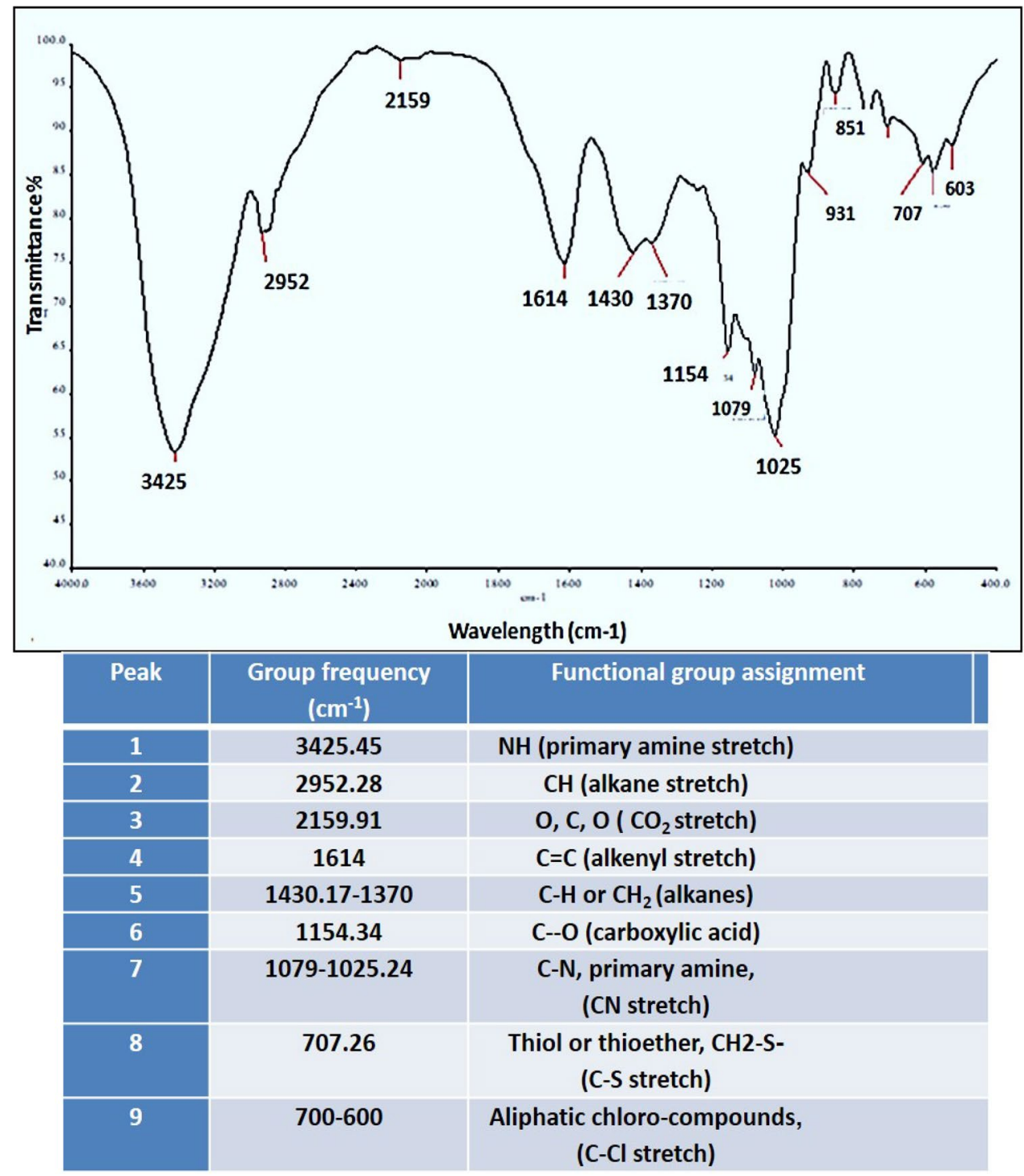

\section{Cytotoxicity and genotoxicity assessment}

The cytotoxicity of tested samples was measured against Peripheral Blood Lymphocytes normal cells and HepG2 malignant cell lines using the MTT assay, as well as against Human Skin Fibroblast (HSF) normal cell lines using the SRB assay. Analysis of cytotoxicity by MTT assay assured the non-cytotoxic impact of biosynthesized Ag-NPs on normal tested cells (Fig. 7 and Table 3). Results revealed that the biosynthesized Ag-NPs have no cytotoxic effect on different cell lines in the tested range $(48-500 \mu \mathrm{g} / \mathrm{mL})$. The cytotoxic effect of biosynthesized Ag-NPs showed $\mathrm{IC}_{50}$ of $1147 \mu \mathrm{g} / \mathrm{mL}$ for HepG2, $8210 \mu \mathrm{g} / \mathrm{mL}$ for normal Peripheral Blood Lymphocytes, and $<300 \mu \mathrm{g} / \mathrm{mL}$ for HSF normal cell lines. The biosynthesized Ag-NPs have no harmful effect on the cell viability of normal Blood Lymphocytes which was almost the same ( $<90 \%$ viability) for all tested concentrations. Overall, the biosynthesized Ag-NPs (Fig. 7 and Table 3) had significantly higher $\mathrm{IC}_{50}$ than its $\mathrm{MBC}$ values $(97-195 \mu \mathrm{g} / \mathrm{mL})$ against the two studied multidrugresistant pathogens (K. pneumonia and L. monocytogenes).

Comet assay was performed on treated peripheral Blood Lymphocytes to evaluate the genotoxic potential of biosynthesized Ag-NPs. Results showed no fragmentation of DNA and no tail formation for all tested concentrations using Comet electrophoresis (Fig. 8). This is the first report for the genotoxicity assessment of biosynthesized Ag-NPs on peripheral Blood Lymphocytes. No genotoxic was recorded in all treated samples and data obtained (Fig. 8) showed that tail migration is zero and head intensity is $100 \%$. 


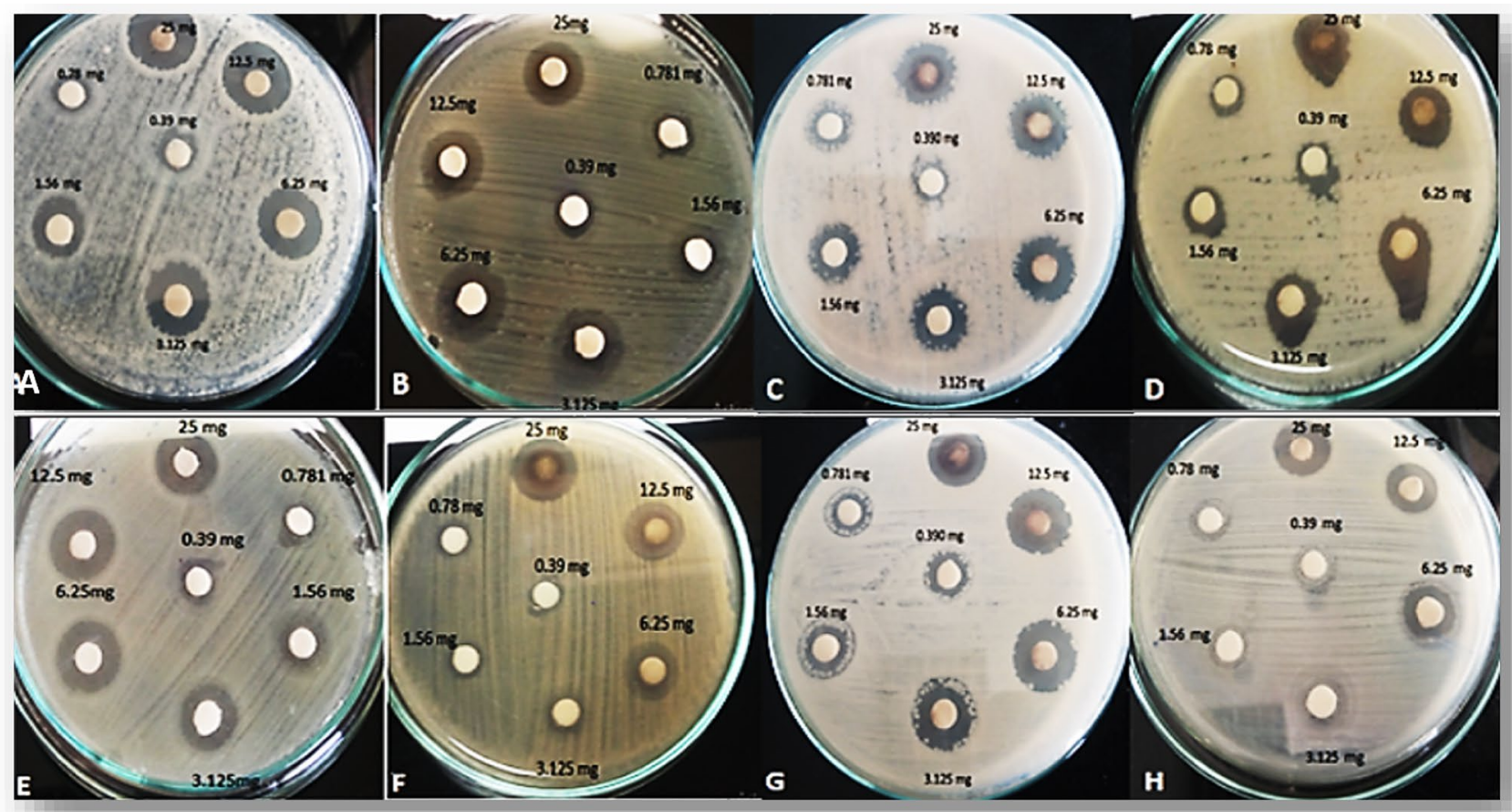

Fig. 5 Antimicrobial activity of biosynthesized Ag-NPs was tested using disc diffusion method by two-fold dilution against $L$. monocytogenes (A), S. aureus $(\mathbf{B})$, B. subtilis $(\mathbf{C})$, B. cereus $(\mathbf{D})$, E. coli $\mathrm{O} 157: \mathrm{H} 7$ (E), A. hydrophilia $(\mathbf{F})$, K. pneumonia $(\mathbf{G})$, and C. albicans $(\mathrm{H})$

Table 1 Antimicrobial activity of Ag-NPs biosynthesized by S. roseolus against different multidrug-resistant strains, measured as inhibition zone diameter in $\mathrm{mm}$

\begin{tabular}{|c|c|c|c|c|c|c|c|c|}
\hline \multirow[t]{3}{*}{ Conc. (mg/mL) } & \multicolumn{8}{|c|}{ Zone of Inhibition (mm) } \\
\hline & \multicolumn{4}{|c|}{ Gram-positive strains } & \multicolumn{3}{|c|}{ Gram-negative strains } & \multirow{2}{*}{$\begin{array}{l}\text { Yeast } \\
\text { C. albicans* }\end{array}$} \\
\hline & L. monocytogenes & B. cereus & B. subtilis & S. aureus & $\begin{array}{l}\text { Aeromonas } \\
\text { hydrophilia }\end{array}$ & E. coli $\mathrm{O} 157: \mathrm{H}^{*} *$ & K. pneumonia & \\
\hline 25 & $20.00 \pm 0$ & $20.00 \pm 0.3$ & $19.66 \pm 0.3$ & $20.66 \pm 0.3$ & $21.00 \pm 0.3$ & $23.66 \pm 0$ & $22.00 \pm 0.3$ & $18.66 \pm 0.3$ \\
\hline 12.5 & $18.00 \pm 0.3$ & $18.5 \pm 0.3$ & $17.00 \pm 0$ & $18.66 \pm 0.3$ & $19.00 \pm 0.3$ & $22.66 \pm 0$ & $19.00 \pm 0.3$ & $17.66 \pm 0.3$ \\
\hline 6.25 & $16.66 \pm 0.3$ & $16.33 \pm 0.3$ & $15.66 \pm 0.3$ & $17.33 \pm 0.3$ & $16.50 \pm 0.5$ & $17.33 \pm 0.4$ & $17.50 \pm 0.3$ & $15.00 \pm 0$ \\
\hline 3.125 & $14.33 \pm 0.3$ & $14.33 \pm 0.3$ & $13.66 \pm 0.3$ & $15.33 \pm 0.3$ & $14.50 \pm 0.5$ & $18.33 \pm 0.4$ & $15.00 \pm 0.3$ & $13.00 \pm 0.3$ \\
\hline 1.56 & $11.66 \pm 0.3$ & $11.66 \pm 0.3$ & $11.66 \pm 0.3$ & $14.00 \pm 0.5$ & $12.00 \pm 0.5$ & $15.66 \pm 0$ & $13.00 \pm 0$ & $12.50 \pm 0.3$ \\
\hline 0.78 & $9.66 \pm 0.3$ & $9.66 \pm 0.3$ & $8.66 \pm 0.3$ & $12.33 \pm 0.3$ & $10.50 \pm 0.3$ & $13.00 \pm 0.3$ & $10.50 \pm 0$ & $9.66 \pm 0.3$ \\
\hline 0.39 & $7.33 \pm 0.3$ & $7.33 \pm 0.3$ & $6.33 \pm 0.3$ & $10.33 \pm 0.3$ & $8.50 \pm 0$ & $10.00 \pm 0$ & $8.50 \pm 0.3$ & $6.66 \pm 0.3$ \\
\hline $\mathrm{AgNO}_{3}$ & $5.00 \pm 0.3$ & $5.00 \pm 0.3$ & $4.00 \pm 0.3$ & $6.00 \pm 0.5$ & $5.00 \pm 0.3$ & $6.00 \pm 0.3$ & $5.00 \pm 0$ & $5.00 \pm 0.5$ \\
\hline $\begin{array}{l}\text { S. roseolus Superna- } \\
\text { tant }\end{array}$ & 0 & 0 & 0 & 0 & 0 & 0 & 0 & 0 \\
\hline
\end{tabular}

Data are average d of 3 replicates \pm SD (standard deviation). One-way ANOVA showed that the $P$ value $<0.05$, suggesting significant effect of nano-silver on different microorganisms, Tukey HSD* test showed that the only significant variance was between $E$. coli and $C$. albicans with $P$ value $<0.05$ 
Table 2 The antibacterial activity of biosynthesized Ag-NPs determined as MIC and MBC using agar dilution and broth macro-dilution methods

\begin{tabular}{|c|c|c|c|c|}
\hline \multirow{2}{*}{$\begin{array}{l}\text { Concentration } \\
(\mu \mathrm{g} / \mathrm{mL})\end{array}$} & \multicolumn{2}{|c|}{ Listeria monocytogenes } & \multicolumn{2}{|c|}{ Klebsiella pneumonia } \\
\hline & Agar dilution & $\begin{array}{l}\text { Broth } \\
\text { macro- } \\
\text { dilution }\end{array}$ & Agar dilution & $\begin{array}{l}\text { Broth } \\
\text { macro- } \\
\text { dilution }\end{array}$ \\
\hline MIC & 195 & 97 & 48 & 24 \\
\hline MBC & 195 & 195 & 97 & 48 \\
\hline $\begin{array}{c}\text { Tolerance level } \\
\text { (MBC/MIC) }\end{array}$ & 1 & 2 & 2 & 2 \\
\hline
\end{tabular}

$\mathrm{MBC} / \mathrm{MIC}$ ratio $\geq 16$, the antimicrobial agent is considered bacteriostatic, and $\mathrm{MBC} / \mathrm{MIC}$ ratio $\leq 4$, the agent is considered bactericidal

\section{Discussion}

\section{Biosynthesis of Ag-NPs, and molecular identification of the selected isolate}

In this study, Ag-NPs were successfully synthesized extracellularly within $6 \mathrm{~h}$ only, using the culture supernatant of Streptomyces strain newly isolated from the Egyptian soil. The biological synthesis of Ag-NPs has received great attention owing to their eco-friendly and cost-effective process. The surface of Ag-NPs is coated with different biomolecules from the Streptomyces supernatant making them biocompatible and more safe. Therefore, biological synthesis can offer interesting applications in biomedicine and other related fields (Sharma et al. 2019). The selected isolate was molecularly identified using $16 \mathrm{~S}$ rRNA gene sequencing. The NCBI database and phylogenetic tree showed $98.74 \%$ similarity with Streptomyces
Fig. 6 SEM micrograph showing the antimicrobial action of biosynthesized Ag-NPs against L. monocytogenes (A), and $K$. pneumonia (B) at MIC concentration after $3 \mathrm{~h}(\mathbf{C}, \mathbf{D})$ and $6 \mathrm{~h}$ of incubation $(\mathbf{E}, \mathbf{F})$

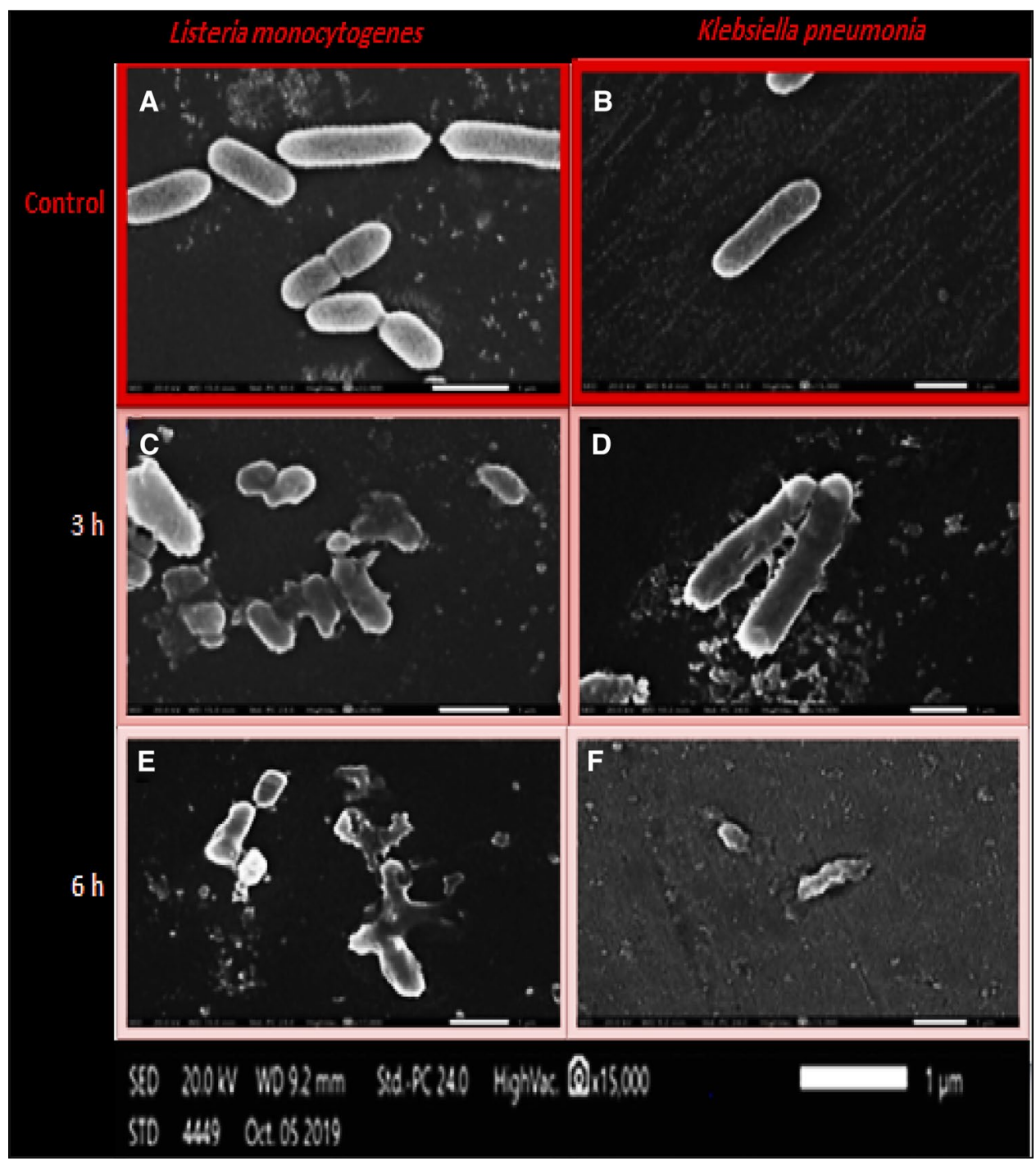



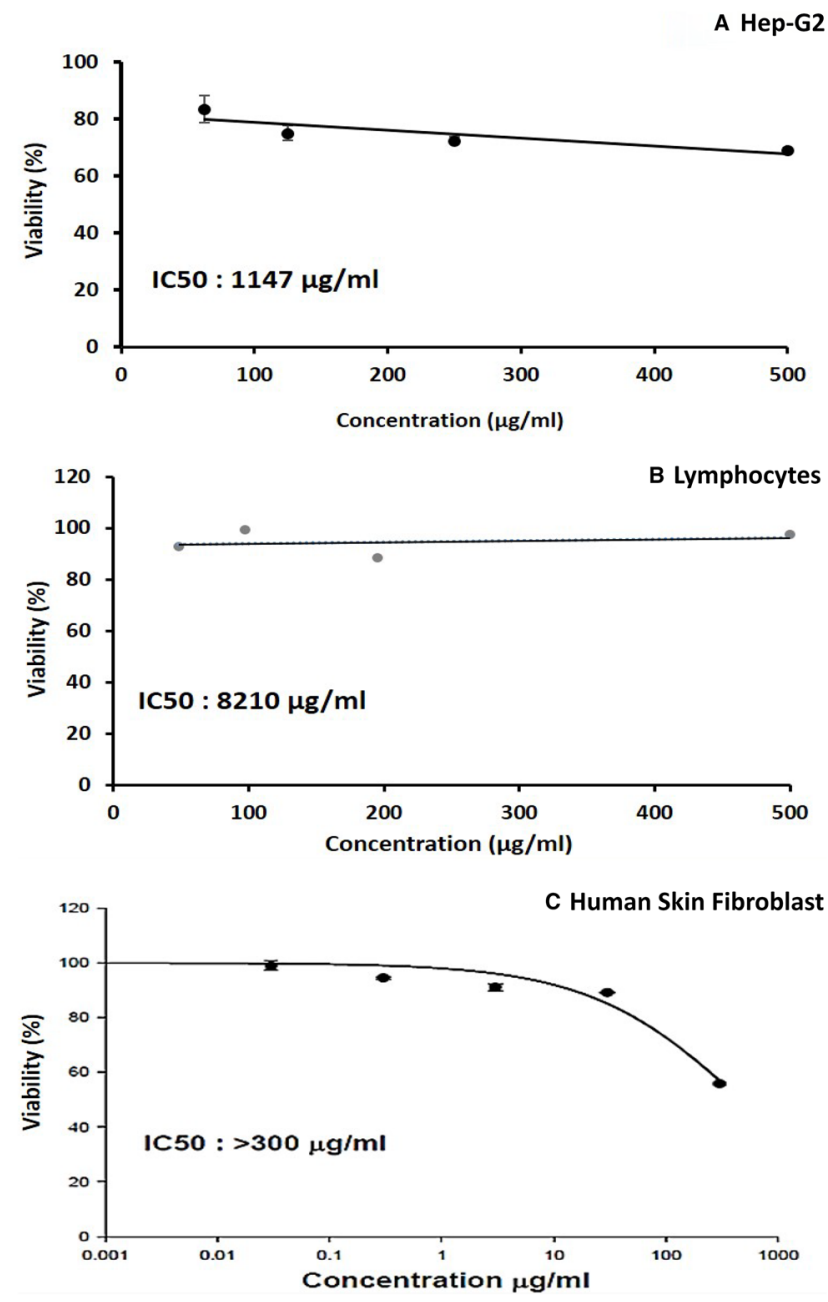

Fig. 7 Cytotoxic effect of biosynthesized Ag-NPs against Hep-G2 (A), lymphocytes (B) using MTT assay $(\mathrm{n}=3)$, and HSF $(\mathbf{C})$, using SRB assay, data expressed as the mean value of cell viability (\% of control) \pm S.D. IC $_{50}$ was calculated to be $1147 \mu \mathrm{g} / \mathrm{mL}, 8210 \mu \mathrm{g} / \mathrm{mL}$, and $<300 \mu \mathrm{g} / \mathrm{mL}$, respectively

roseolus strain (NBRC 12,816), with a high genetic relationship confirming its identity as Streptomyces roseolus (Fig. 1).

\section{Characterization of biomediated Ag-NPs}

The strong and broad surface-plasmon-resonance (SPR) band that was observed at $470 \mathrm{~nm}$, is characteristic for Ag-NPs (Fig. 2). The intensity of SPR peaks detected by UV-Vis spectroscopy was increased probably due to the increase in Ag-NPs concentration (Ibrahim 2015). Similarly, Alsamhary (2020) reported that Ag-NPs were biosynthesized using $B$. subtilis with a strong broad peak between 400 and $470 \mathrm{~nm}$ indicating the formation of $\mathrm{Ag}$ NPs. XRD pattern showed characteristic XRD diffraction peaks as indexed planes of cubic face-centered silver. XRD spectrum was compared with the standard published by the Joint Committee on Powder Diffraction Standards (file no. 04-0783), confirming the crystalline nature of produced AgNPs. The peaks intensity reflects the high degree of AgNPs crystallinity (Fig. 2). Similarly, Bakhtiari-Sardari et al. (2020) synthesized Ag-NPs using Streptomyces sp. OSIP1 with diffraction peaks typical to face-centered cubic silver at 38.2 (111), 44.4 (200), 64.6 (220), and 77.5 (311) corresponding to the crystalline planes of Ag. DLS measures the hydrodynamic diameter of NPs, which is higher than its actual diameter obtained from TEM images, and relating the number \% with its PDI, it is suggested that the produced $\mathrm{Ag}$ NPs were highly dispersive (Fig. 3). FTIR analysis (Fig. 4) verified the presence of different functional groups on the surface of biosynthesized Ag-NPs due to the biomolecules in the Streptomyces supernatant, that act as reducing and stabilizing agent for the produced Ag-NPs (Zhang et al. 2016). Specific strong absorption bands at $3420 \mathrm{~cm}^{-1}(\mathrm{~N}-\mathrm{H}$ stretch) were characteristic of the amine group (Mourdikoudis et al. 2018). Strong band at $2952 \mathrm{~cm}^{-1}$ was assigned to aldehydic C-H stretching (Sharma et al. 2019) and bands at $1614 \mathrm{~cm}^{-1}$ and $1430 \mathrm{~cm}^{-1}$ were assigned to the absorption peaks of $(\mathrm{C}=\mathrm{C})$ alkyl and $(-\mathrm{C}-\mathrm{H})$ alkanes, respectively (Mourdikoudis et al. 2018). Different absorbance peaks at 1370,1154 , and $1062 \mathrm{~cm}^{-1}$ were related to $\mathrm{CH}_{2}$ of alkanes, $\mathrm{C}-\mathrm{O}$ of carboxylic acid, and $(\mathrm{C}-\mathrm{N})$ stretching, respectively (Ghaseminezhad et al. 2012; Ibrahim 2015). The amide and aromatic group residues of proteins have a stronger ability to bind metals and form a surface layer on metallic Ag-NPs confirming that proteins act as a capping agent for stabilization (Malarkodi et al. 2013).

\section{Antimicrobial activity of Ag-NPs, tolerance level, and SEM imaging}

Chemical antimicrobial agents are limited to use because various microorganisms have established resistance properties over generations. Ag-NPs have a significant advantage as compared to conventional chemical antimicrobial agents towards the multidrug-resistance problem, and this is because bacteria are less probable to develop resistance to metallic NPs as compared to conventional antibiotics (Loo et al. 2018). The highest antimicrobial activity was against Gram-negative (Table 1 and Fig. 5) probably due to the cell wall structure (Erjaee et al. 2017). Similarly, Huq and Akter (2021) reported that the extracellularly biosynthesized Ag-NPs by Paenarthrobacter nicotinovorans MAHUQ-43 exhibited higher antibacterial activity against the Gramnegative $P$. aeruginosa $(24.7 \mathrm{~mm})$ than Gram-positive $B$. cereus $(19.3 \mathrm{~mm})$.

The tolerance level should be evaluated to determine if the biosynthesized Ag-NPs have a bactericidal or bacteriostatic effect against tested pathogenic strains. When MBC/MIC 
Table 3 Mean value of cell viability of normal and HepG cell-lines (\% of control) \pm S.D at different concentrations of biosynthesized Ag-NPs. $\mathrm{IC}_{50}$ was calculated in $\mu \mathrm{g} / \mathrm{mL}$

\begin{tabular}{lllll}
\hline Cell line & Concentration & Viability mean & $\begin{array}{l}\text { Standard } \\
\text { deviation }\end{array}$ & $\mathrm{IC}_{50}(\mu \mathrm{g} / \mathrm{mL})$ \\
\hline Human skin fibroblast & Control & 100 & 0 & \\
& 0.03 & 98.90 & 1.69 & \\
& 0.3 & 94.52 & 0.48 & 1.24 \\
Hepatocellular carcinoma & 3 & 91.12 & 0.054 & \\
& 30 & 89.13 & 0.42 & \\
& 300 & 55.85 & 0.63 & \\
& 500 & 69.16 & 1.25 & \\
Peripheral blood lymphocytes & 250 & 72.59 & 2.73 & \\
& 125 & 75.15 & 4.75 & \\
& 62.5 & 83.60 & 2.6 & \\
& 500 & 97.64 & 14.5 & \\
& 195 & 88.54 & 8.9 & \\
\hline
\end{tabular}
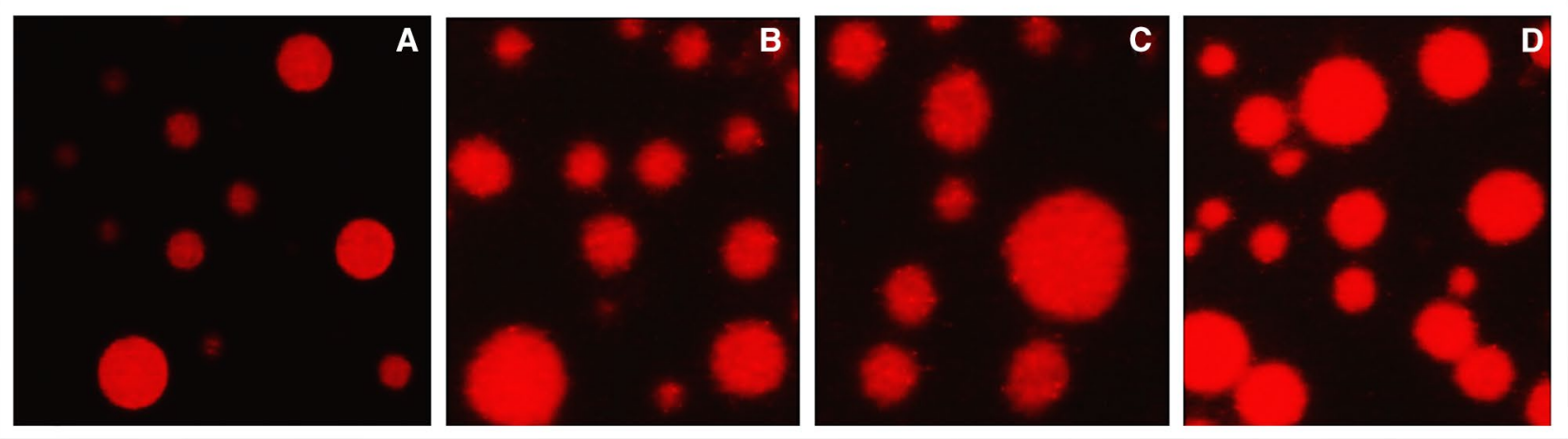

Fig. 8 Single cell gel electrophoresis comet analysis of untreated (A) and peripheral Blood Lymphocytes (B, C, D) treated with different concentration of biosynthesized Ag-NPs

ratio is $\geq 16$, the antimicrobial agent is considered bacteriostatic, and when the ratio is $\leq 4$, the agent is considered bactericidal (Das et al. 2017). The National Clinical Committee for Laboratory Standards reported that an agent is considered bactericidal when it causes $99.9 \%$ reduction in CFU/ $\mathrm{mL}$ after $18-24 \mathrm{~h}$ of incubation in broth media, however, the microbe is considered as tolerant if its MBC is higher than its MIC by 32-fold or more (Woods and Washington 1995). The tolerance level of 2 , for L. monocytogenes, and $K$. pneumonia confirmed that biosynthesized Ag-NPs have a biocidal effect against both pathogens (Table 2). TreatedL. monocytogenes and K. pneumonia with Ag-NPs (Fig. 6) showed notable morphological alterations as compared to the control suggesting the bactericidal effect of biosynthesized Ag-NPs (Sondi and Salopek-Sondi 2004). Likewise, Sondi and Salopek-Sondi (2004) reported that the antimicrobial activity of Ag-NPs against E. coli, is probably due to pits formation in the cell wall of treated-pathogen, leading to its death. The peptidoglycan protein layer in bacterial cell wall is negatively charged making more positively charged $\mathrm{Ag}^{+}$ions get stuck in Gram-positive than in Gram-negative. The thicker cell walls of Gram-positive slows down the passage of Ag-NPs and thus, allows fewer Ag-NPs to reach the cytoplasmic membrane. As a result, Gram-negative bacteria are more susceptible than Gram-positive (Ahmed et al. 2016; Erjaee et al. 2017). In addition, the uptake, accumulation, and translocation of Ag-NPs inside the cells depend on the structure of cells, their permeability, and also the size of NPs (Li et al. 2015). Tripathi et al. (2017) reported that $\mathrm{Ag}^{+}$ions can accumulate in the cytoplasm or near cell wall, disrupting the membrane permeability, and facilitating the entrance of Ag-NPs which inhibits the respiratory enzyme(s), and allows the production of reactive oxygen species (Das et al. 2017). Furthermore, Ag-NPs bind to thiol groups (-SH) of enzymes, causing deactivation of enzymes (Ahmed et al. 2016). Moreover, Shahverdi et al. (2007) proposed that $\mathrm{Ag}^{+}$ 
ions can enter the cell and disrupt the hydrogen bonding between DNA strands, denaturing it, so the DNA loses its replication capability and expression of ribosomal proteins.

\section{Cytotoxicity and genotoxicity assessment}

Cytotoxicity is an important factor that affects the safety applications of Ag-NPs (Fig. 7). Dermal contact is one of the most common ways of NPs exposure (Schneider et al. 2009). Therefore, NPs can be used in cosmetics if only their effect and absorption were evaluated on the skin (Kong et al. 2011). So, the use of standard HSF cell lines would be effective to screen in vitro cytotoxicity of the produced Ag-NPs (Fig. 7). The lower toxicity observed on normal cell lines is probably due to the biomolecules present in the biological source used for biosynthesis and capping of Ag-NPs, which influenced its properties (Roy et al. 2019). The potential cytotoxicity of NPs depends on the routes of administration and NPs characteristics, such as size, shape, concentration, and time exposure as well as the capping agent used for stabilization (Niska et al. 2016; Tayel et al. 2017). The effect of different capping agents on cytotoxicity was investigated by Niska et al. (2016) using spherical-shaped Ag-NPs capped with lipoic acid (AgNPs-LA), polyethylene glycol (AgNPsPEG), or tannic acid (AgNPs-TA), and compared with uncapped ones against human gingival fibroblast cells using MTT assay. Capped-AgNPs-LA had the lowest cytotoxicity, followed by AgNPs-PEG, and AgNPs-TA. This difference in cytotoxicity clearly reveal the influence of capping agents on Ag-NPs cytotoxicity. Furthermore, Paknejadi et al. (2018) reported that chemically-prepared Ag-NPs exhibited higher cytotoxicity on normal $\mathrm{HSF}$ cell lines with $\mathrm{IC}_{50}$ values of $30.64 \mu \mathrm{g} / \mathrm{mL}$, after $24 \mathrm{~h}$ of incubation. Similarly, Kummara et al. (2016) biosynthesized AgNPs using Azadirachta indica leaves extract and compared its cytotoxic effect against HDF cell lines. The biosynthesized AgNPs treatment at different concentrations $(0-240 \mu \mathrm{g} / \mathrm{mL})$ didn't decrease the viability of HDF cells even at higher concentrations, while, chemically synthesized Ag-NPs showed significant toxicity confirming that biosynthesized AgNPs were much safer on normal HDF than chemically synthesized ones. However, the $\mathrm{IC}_{50}$ of biosynthesized AgNPs was $60 \mu \mathrm{g} / \mathrm{mL}$ on HDF cell lines (Kummara et al. 2016) which is lower than the biosynthesized one in the current study.

Genotoxicity using Comet assay provides new insight for complete risk assessment of Ag-NPs (Narciso et al. 2020). One of the major issues in the identification of Ag-NPs hazards is its genotoxic potential which is identified by the European Food Safety Authority (EFSA) as an important step in safety evaluation (EFSA Scientific Committee et al. 2016). Genotoxicity data provides a more comprehensive risk assessment of Ag-NPs (Fig. 8). The Comet assay is often used in nano-genotoxicology to identify substances that can cause DNA damage (Glei et al. 2016). The Comet assay is a sharp, easy, and flexible assay used for the identification of DNA degradation in eukaryotic cells. It enables the detection of cross-links, and disruption of double-stranded DNA (Sharma et al. 2021). Similarly, Narciso et al. (2020) reported no genotoxic damage by Comet assay in mice tissues (blood, spleen, liver, kidney, and duodenum) when exposed orally to Ag-NPs of $50-300 \mathrm{mg} / \mathrm{kg}$.wt/day for 3 days. In contrast, Patlolla et al. (2015) reported a significant increase in the genotoxic effects, such as chromosome aberrations, and damaged DNA in Ag-NPs-treated rats for 5 days, at doses of 5-100 mg/Kg.wt/day. Collectively, different physicochemical characteristics, including size, shape, and administration route can lead to different biological activities, thus affecting the outcome of hazard identification (Tayel et al. 2017; Narciso et al. 2020). Overall, the biosynthesized Ag-NPs in this study had significantly higher $\mathrm{IC}_{50}$ than its $\mathrm{MBC}$ values against the two studied multidrugresistant pathogens (K. pneumonia and L. monocytogenes) with no detected genotoxicity. Consequently, it is safer to be used as an effective safe antimicrobial agent at its biocidal concentration.

\section{Conclusion}

Streptomyces roseolus was isolated from the Egyptian soil and molecularly identified using $16 \mathrm{~S}$ rRNA gene sequencing. S. roseolus was efficiently used for the first time as a simple, green, cost-effective new bio-reducing agent for extracellular biosynthesis of Ag-NPs, after $6 \mathrm{~h}$ only at room temperature. The produced Ag-NPs was characterized using UV-Vis spectroscopy, TEM, DLS, FTIR, and XRD. FTIR analysis confirmed the bio-reduction of $\mathrm{Ag}^{+}$ions to $\mathrm{Ag}-\mathrm{NPs}$ and its stabilization by different biomolecules in $S$. roseolus supernatant, which probably influenced its biosafety. The MBC of the biosynthesized Ag-NPs against L. monocytogenes and K. pneumonia were 195 and $48 \mu \mathrm{g} / \mathrm{mL}$, respectively, with a tolerance level of 2 confirming its biocidal effect. SEM imaging showed destruction of treated pathogen cells after $6 \mathrm{~h}$ of exposure to MIC. Biosynthesized Ag-NPs showed $\mathrm{IC}_{50}$ of $8210 \mu \mathrm{g} / \mathrm{mL}$ for normal Blood Lymphocytes, and $<300 \mu \mathrm{g} / \mathrm{mL}$ for Human Skin Fibroblast cell lines, which is way higher than other published reports, assuring its safe application as antiseptic and in dermal practice. In the current study, no genotoxicity was recorded for the produced biogenic nano-silver on peripheral Blood Lymphocytes using Comet assay, with zero tail migration and 100\% head intensity. The biosynthesized Ag-NPs exhibited strong antimicrobial activity, with no harmful effect on different normal cell lines, indicating their safe usage at their biocidal concentration in many industrial applications. 
Acknowledgements The authors gratefully acknowledge the fund support of this work by Academy of Scientific Research and Technology (ASRT), EGYPT, who awarded Master scholarship (Scientists for Next Generation) to Miss Asmaa El Nady at GEBRI, University of Sadat City. The authors would like to thank Dr. Omiama Khamiss Professor of Animal Science and Dr. Roba Talaat Professor of Immunology, at GEBRI, University of Sadat City, for their help in the cytotoxicity and Comet assessments.

Author contributions Conceptualization, writing, editing, and supervision: NS and RA. Laboratory work, and data analysis: AE, RA. All authors read and approved the final manuscript.

Funding Open access funding provided by The Science, Technology \& Innovation Funding Authority (STDF) in cooperation with The Egyptian Knowledge Bank (EKB).This work was funded by Academy of Scientific Research and Technology (ASRT), EGYPT, who awarded Master scholarship (Scientists for Next Generation) to Miss Asmaa El Nady at GEBRI, University of Sadat City, Egypt.

\section{Declarations}

Conflict of interest All authors declare that there are no financial/commercial conflict of interest.

Open Access This article is licensed under a Creative Commons Attribution 4.0 International License, which permits use, sharing, adaptation, distribution and reproduction in any medium or format, as long as you give appropriate credit to the original author(s) and the source, provide a link to the Creative Commons licence, and indicate if changes were made. The images or other third party material in this article are included in the article's Creative Commons licence, unless indicated otherwise in a credit line to the material. If material is not included in the article's Creative Commons licence and your intended use is not permitted by statutory regulation or exceeds the permitted use, you will need to obtain permission directly from the copyright holder. To view a copy of this licence, visit http://creativecommons.org/licenses/by/4.0/.

\section{References}

Abd-Elnaby HM, Abo-Elala GM, Abdel-Raouf UM, Hamed MM (2016) Antibacterial and anticancer activity of extracellular synthesized silver nanoparticles from marine Streptomyces rochei MHM13. Egyp J Aquatic Res 42(3):301-312

Ahmed S, Ahmad M, Swami BL, Ikram S (2016) A Review on plants extract mediated synthesis of silver nanoparticles for antimicrobial applications: a green expertise. J Adv Res 7:17-28

Alsamhary KI (2020) Eco-friendly synthesis of silver nanoparticles by Bacillus subtilis and their antibacterial activity. Saudi J Biol Sci 27:2185-2191

Anandaradje A, Meyappan V, Kumar I, Sakthivel N (2020) Microbial synthesis of silver nanoparticles and their biological potential. Nanoparticles in Medicine, Springer, pp 99-133

Andrews JM (2001) Determination of minimum inhibitory concentrations. J Antimicrob Chemother 48:5-16

Bakhtiari-Sardari A, Mashreghi M, Eshghi H, Behnam-Rasouli F, Lashani E, Shahnavaz B (2020) Comparative evaluation of silver nanoparticles biosynthesis by two cold-tolerant streptomyces strains and their biological activities. Biotech Lett 42:1985-1999
Crisan CM, Mocan T, Manolea M, Lasca LI, Tăbăran F-A, Mocan L (2021) Review on silver nanoparticles as a novel class of antibacterial solutions. Appl Sci 11:1120

Das B, Dash SK, Mandal D, Ghosh T, Chattopadhyay S, Tripathy S, Das S, Dey SK, Das D, Roy S (2017) Green synthesized silver nanoparticles destroy multidrug resistant bacteria via reactive oxygen species mediated membrane damage. Arab J Chem 10:862-876

EFSA Panel On Food Additives and Nutrient Sources Added To Food (2016) Scientific opinion on the re-evaluation of silver (E 174) as food additive. EFSA J 14(1):4364

El-Baz AF, Sorour NM, Shetaia YM (2016) Trichosporon jiroveciimediated synthesis of cadmium sulfide nanoparticles. J Basic Microbiol 56:520-530

Erjaee H, Rajaian H, Nazifi S (2017) Synthesis and characterization of novel silver nanoparticles using chamaemelum nobile extract for antibacterial application. Adv Nat Sci 8:025004

Fissan H, Ristig S, Kaminski H, Asbach C, Epple M (2014) Comparison of different characterization methods for nanoparticle dispersions before and after aerosolization. Anal Methods 6:7324-7334

Fakhr AE, Fathy FM (2018) Bacterial pattern and risk factors of hospital acquired infections in a tertiary care hospital, Egypt. Egyp J Med Microbiol 27:9-16

Ghaseminezhad SM, Hamedi S, Shojaosadati SA (2012) Green synthesis of silver nanoparticles by a novel method: comparative study of their properties. Carbohyd Polym 89:467-472

Glei M, Schneider T, Schlörmann W (2016) Comet assay: an essential tool in toxicological research. Arch Toxicol 90(10):2315-2336

Hansen MB, Nielsen SE, Berg K (1989) Re-examination and further development of a precise and rapid dye method for measuring cell growth/cell kill. J Immunol Methods 119:203-210

Hassan A, Sorour NM, El-Baz A, Shetaia Y (2019) Simple synthesis of bacterial cellulose/magnetite nanoparticles composite for the removal of antimony from aqueous solution. Int J Environ Sci Technol 16:1433-1448

Hassan R, Gilany AH, Elaal AM (2021) Anti-biotic resistance pattern of bacteria causing hospital acquired infections in the new mansoura general hospital, Egypt. Arch Commun Med 3:16-21

Huq M, Akter S (2021) Bacterial mediated rapid and facile synthesis of silver nanoparticles and their antimicrobial efficacy against pathogenic microorganisms. Materials 14:2615

Ibrahim HM (2015) Green synthesis and characterization of silver nanoparticles using banana peel extract and their antimicrobial activity against representative microorganisms. J Radiat Res Appl Sci 8:265-275

Kim M, Morrison M, Yu Z (2011) Evaluation of different partial 16S Rrna gene sequence regions for phylogenetic analysis of microbiomes. J Microbiol Methods 84:81-87

Kizhakeyil A, Ong ST, Fazil MHUT, Chalasani MLS, Prasannan P, Verma NK (2019) Isolation of human peripheral blood t-lymphocytes. T-Cell Motility, Springer, pp 11-17

Klančnik A, Piskernik S, Jeršek B, Možina SS (2010) Evaluation of diffusion and dilution methods to determine the antibacterial activity of plant extracts. J Microbiol Methods 81:121-126

Kong B, Seog JH, Graham LM, Lee SB (2011) Experimental considerations on the cytotoxicity of nanoparticles. Nanomedicine 6:929-941

Kummara S, Patil MB, Uriah T (2016) Synthesis, characterization, biocompatible and anticancer activity of green and chemically synthesized silver nanoparticles-a comparative study. Biomedicine, Pharmacotherapy 84:10-21

Li X, Schirmer K, Bernard L, Sigg L, Pillai S, Behra R (2015) Silver nanoparticle toxicity and association with the alga Euglena gracilis. Environ Sci Nano 2:594-602

Loo YY, Rukayadi Y, Nor-Khaizura MA, Kuan CH, Chieng BW, Nishibuchi M, Radu S (2018) In vitro antimicrobial activity of 
green synthesized silver nanoparticles against selected gramnegative foodborne pathogens. Front Microbiol 9:1555

Malarkodi C, Rajeshkumar S, Paulkumar K, Vanaja M, Jobitha GDG, Annadurai G (2013) Bactericidal activity of bio mediated silver nanoparticles synthesized by Serratia nematodiphila. Drug Invention Today 5:119-125

Martínez G, Merinero M, Pérez-Aranda M, Pérez-Soriano EM, Ortiz T, Begines B, Alcudia A (2021) Environmental impact of nanoparticles' application as an emerging technology: a review. Materials $14: 166$

May J, Shannon K, King A, French G (1998) Glycopeptide tolerance in Staphylococcus aureus. J Antimicrob Chemother 42:189-197

Mourdikoudis S, Pallares RM, Thanh NT (2018) Characterization techniques for nanoparticles: comparison and complementarity upon studying nanoparticle properties. Nanoscale 10:12871-12934

Narciso L, Coppola L, Lori G, Andreoli C, Zjino A, Bocca B, Petrucci F, Di Virgilio A, Martinelli A, Tinari A, Maranghi F (2020) Genotoxicity, biodistribution and toxic effects of silver nanoparticles after in vivo acute oral administration. Nanoimpact 18:100221

Niska K, Knap N, Kędzia A, Jaskiewicz M, Kamysz W, InkielewiczStepniak I (2016) Capping agent-dependent toxicity and antimicrobial activity of silver nanoparticles: an in vitro study. Concerns about potential application in dental practice. Int J Med Sci 13:772

Paknejadi M, Bayat M, Salimi M, Razavilar V (2018) Concentrationand time-dependent cytotoxicity of silver nanoparticles on normal human skin fibroblast cell line. Iran Red Crescent Med J 20

Patlolla AK, Hackett D, Tchounwou PB (2015) Silver nanoparticleinduced oxidative stress-dependent toxicity in sprague-dawley rats. Mol Cell Biochem 1:257-268

Roy A, Bulut O, Some S, Mandal AK, Yilmaz MD (2019) Green synthesis of silver nanoparticles: biomolecule-nanoparticle organizations targeting antimicrobial activity. RSC Adv 9:2673-2702

Saied T, Elkholy A, Hafez SF, Basim H, Wasfy MO, El-Shoubary W, Samir A, Pimentel G, Talaat M (2011) Antimicrobial resistance in pathogens causing nosocomial bloodstream infections in university hospitals in Egypt. Am J Infect Control 39:E61-E65

Schneider M, Stracke F, Hansen S, Schaefer UF (2009) Nanoparticles and their interactions with the dermal barrier. Dermato-Endocrinology 1:197-206

Shahverdi AR, Fakhimi A, Shahverdi HR, Minaian S (2007) Synthesis and effect of silver nanoparticles on the antibacterial activity of different antibiotics against staphylococcus aureus and Escherichia coli. Nanomedicine 3:168-171

Sharma D, Shandilya P, Saini NK, Singh P, Thakur VK, Saini RV, Mittal D, Chandan G, Saini V, Saini AK (2021) Insights into the synthesis and mechanism of green synthesized antimicrobial nanoparticles, answer to the multidrug resistance. Mater Today Chem 19:100391

Sharma V, Kaushik S, Pandit P, Dhull D, Yadav JP, Kaushik S (2019) Green synthesis of silver nanoparticles from medicinal plants and evaluation of their antiviral potential against chikungunya virus. Appl Microbiol Biotechnol 103:881-891

Singh NP, Mccoy MT, Tice RR, Schneider EL (1988) A simple technique for quantitation of low levels of DNA damage in individual cells. Exp Cell Res 175(1):184-191

Skehan P, Storeng R, Scudiero D, Monks A, Mcmahon J, Vistica D, Warren JT, Bokesch H, Kenney S, Boyd MR (1990) New colorimetric cytotoxicity assay for anticancer-drug screening. JNCI 82:1107-1112

Sondi I, Salopek-Sondi B (2004) Silver nanoparticles as antimicrobial agent: a case study on E. coli as a model for gram-negative bacteria. J Colloid Interface Sci 275:177-182

Srikar SK, Giri DD, Pal DB, Mishra PK, Upadhyay SN (2016) Green synthesis of silver nanoparticles: a review. Green Sustain Chem 6:34-56

Stecher G, Tamura K, Kumar S (2020) Molecular evolutionary genetics analysis (MEGA) for macos. Mol Biol Evol 37:1237-1239

Sumadevi K, Krishnamurthy G, Walmik P, Rani RP, Naik S, Naik HB, Naik N (2021) Photocatalytic degradation of eriochrome black-T and evan's blue dyes under the visible light using PVA capped and uncapped $\mathrm{Ag}$ doped Zns nanoparticles. Emergent Mater 4:447-456

Tamboli DP, Lee DS (2013) Mechanistic antimicrobial approach of extracellularly synthesized silver nanoparticles against gram positive and gram negative bacteria. J Hazard Mater 260:878-884

Tamura K, Nei M (1993) Estimation of the number of nucleotide substitutions in the control region of mitochondrial DNA In humans and chimpanzees. Mol Biol Evol 10:512-526

Tayel AA, Sorour NM, El-Baz AF, Wael F (2017) Nanometals appraisal in food preservation and food-related activities. Food Preservat, Elsevier, pp 487-526

Tripathi DK, Tripathi A, Singh S, Singh Y, Vishwakarma K, Yadav G, Sharma S, Singh VK, Mishra RK, Upadhyay R (2017) Uptake, accumulation and toxicity of silver nanoparticle in autotrophic plants, and heterotrophic microbes: a concentric review. Front Microbiol 8:7

Vanlalveni C, Lallianrawna S, Biswas A, Selvaraj M, Changmai B, Rokhum SL (2021) Green synthesis of silver nanoparticles using plant extracts and their antimicrobial activities: a review of recent literature. RSC Adv 11:2804-2837

Wikler MA (2006) Methods for dilution antimicrobial susceptibility tests for bacteria that grow aerobically: approved standard. CLSI (NCCLS) 26:M7-A7

Woods G, Washington J (1995) The clinician and the microbiology laboratory. principles and practice of infectious diseases, $4^{\text {th }} \mathrm{Ed}$ Churchill Livingstone, Philadelphia, pp 169-199

Wypij M, Czarnecka J, Świecimska M, Dahm H, Rai M, Golinska P (2018) Synthesis, characterization and evaluation of antimicrobial and cytotoxic activities of biogenic silver nanoparticles synthesized from Streptomyces Xinghaiensis of 1 strain. World J Microbiol Biotechnol 34(2):1-3

Yaqoob AA, Umar K, Ibrahim MNM (2020) Silver nanoparticles: various methods of synthesis, size affecting factors and their potential applications-A review. Appl Nanosci 10:1369-1378

Zhang X-F, Liu Z-G, Shen W, Gurunathan S (2016) Silver nanoparticles: synthesis, characterization, properties, applications, and therapeutic approaches. Int J Mol Sci 17:1534

Publisher's Note Springer Nature remains neutral with regard to jurisdictional claims in published maps and institutional affiliations. 